\title{
Synthesis, spectroscopic, biological activities and DFT calculations of nickel(II) mixed-ligand complexes of tridentate Schiff bases
}

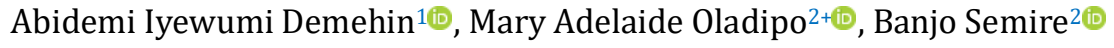

1 Adeyemi College of Education, Department of Chemistry, Ondo, Ondo State, Nigeria

2 Ladoke Akintola University of Technology, Department of Pure and Applied Chemistry, Ogbomoso, Oyo State, Nigeria

+Corresponding author: Mary Adelaide Oladipo, Phone: +234803 3817017 email address: mooladipo@lautech.edu.ng

\section{ARTICLE INFO}

Article history:

Received: March 02, 2019

Accepted: November 11, 2019

Published: January 1, 2020
Keywords:
1. Schiff bases
2. antibacterial
3. antioxidant
4. nickel(II) ion
5. mixed-ligand complex

ABSTRACT: Ni(II) mixed-ligand complexes of [ $\left.\mathrm{NiLNH}_{3}\right]$ (where $\mathrm{L}=\mathrm{N}$-salicylidene-o-aminophenol $\left(\mathrm{L}_{1}\right), \mathrm{N}-(5-$ methoxysalicylidene-o-aminophenol) ( $\left.\mathrm{L}_{2}\right)$ and $\mathrm{N}$-(2-hydroxy-1naphthalidene)-o-aminophenol) $\left(\mathrm{L}_{3}\right)$ containing $\mathrm{ONO}$ tridentate Schiff bases and ammonia were synthesized and characterized by elemental analysis, infrared, ultraviolet-visible, proton and carbon-13 spectroscopies. Theoretical calculations were also performed on the optimized structures of the $\mathrm{Ni}$ (II) mixed-ligand complexes. The infrared and ultraviolet-visible spectra of the complexes were calculated, and the results compared with the corresponding experimental spectra to augment the experimental structural identification. The elemental analysis data confirmed the formation of 1:1:1 [metal:Schiff base:ammonia] molar ratio. The NMR spectra showed that the Schiff bases coordinated to the $\mathrm{Ni}$ (II) ion via the two deprotonated phenolic oxygen and azomethine nitrogen atoms. The biological studies showed that the complexes exhibited higher antibacterial and antioxidant activities than the free Schiff base ligands.
The proposed structures of the synthesized Ni(II) mixed-ligand complexes.

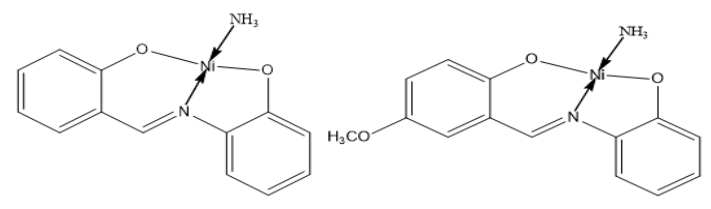

$\mathrm{NiL}_{1} \mathrm{NH}_{3}$ $\mathrm{NiL}_{2} \mathrm{NH}_{3}$

\section{Introduction}

Schiff bases are compounds that are comparable to ketone or aldehyde, they have azomethine $(\mathrm{HC}=\mathrm{N})$ group instead of the carbonyl $(\mathrm{C}=\mathrm{O})$ group in the carbonyl compounds. Schiff bases can also be called azomethines or imines ${ }^{1,2}$. They were discovered by Hugo Schiff in $1864^{3}$. They have the general formula $\mathrm{RR}_{1} \mathrm{C}=\mathrm{N}-\mathrm{R}_{2}$. If $\mathrm{R}$ equals hydrogen, alkyl or aryl, $\mathrm{R}_{1}$ hydrogen and $\mathrm{R}_{2}$ alkyl or aryl; the compounds are referred to as aldimines $\left(\mathrm{R}_{1}-\mathrm{CH}=\mathrm{NR}_{2}\right)$ while compounds where both $\mathrm{R}$ and $\mathrm{R}_{1}$ are alkyl or aryl groups are called ketoimines. $\mathrm{R}_{2}$ can either be an alkyl or aryl group ${ }^{4-6}$. They are significant chelating ligands in coordination chemistry. Their chemical properties can be changed by varying the substituents on either the carbonyl or the amine ring. Intra- and intermolecular hydrogen bonds can be formed from Schiff bases obtained from various substituted salicylaldehydes and 2-hydroxyl-1naphthaldehyde and these usually determine their chemical and physicochemical properties ${ }^{7}$. They have vital donor atoms like nitrogen and oxygen which make them resemble living systems and display different biological properties. The resulting imines are involved in binding with metal ions via nitrogen lone pair of electrons. Schiff bases can bind to the central metal ions as monodentate and polydentate ${ }^{8,9}$. Schiff bases lead to the formation of many mononuclear and binuclear complexes with different coordination modes and stereochemistry ${ }^{8}$. 
The imine groups in Schiff bases are significant for biological activities, they are very useful active centers of many biological systems ${ }^{10}$. Schiff bases have played essential roles in understanding the coordination chemistry of transition metal ions. Studies showed that Schiff bases derived from salicylaldehyde, 2-hydroxyl-1-naphthaldehyde including the derivatives and complexes with some transition metals displayed significant biological properties which make them gain attention. Some of the reported significant biological properties are anti-inflammatory, antimicrobial, analgesic, anticonvulsant and antioxidants which make them attract more attention ${ }^{1,11-19}$.

Many mixed-ligand complexes have been synthesized for their pronounced biological activities. However, literature search showed that reports on mixed-ligand complexes bearing ammonia as co-ligand are less explored. Hence this study, which synthesized, characterized, and carried out the biological and theoretical studies of nickel(II) mixed-ligand complexes of tridentate Schiff bases and ammonia. Besides the experimental studies, quantum chemical methods were used to augment the experimental observations ${ }^{9}$. Therefore, the molecular structures of the Schiff base ligands and complexes were modelled, and the theoretical calculations were carried out on their optimized structures. These were utilized for their IR, UV-Vis and NMR spectra. A consideration of the similarities between the calculated and experimental spectra, mostly the electronic spectra could further be used for identification of the molecular geometry.

\section{Experimental}

\subsection{Materials}<smiles>[R]c1ccc(O)c(C=O)c1</smiles><smiles>Nc1ccccc1O</smiles><smiles>[R]c1ccc(O)c(/C=N/c2ccccc2O)c1</smiles>

Salicylaldehyde, 5-methoxysalicylaldehyde, 2hydroxy-1-naphthaldehyde, $o$-aminophenol, nickel(II) acetate tetrahydrate, ammonium hydroxide and formic acid were purchased from Merck (Germany) and used as supplied. The solvents were of pure grade except ethanol and water which were distilled.

\subsection{Instruments}

A Thermo Finnigan Flash EA 1112 Series was used for the elemental analyses $(\mathrm{C}, \mathrm{H}, \mathrm{N})$. The Infrared spectroscopy analysis were carried out using the attenuated (ATR) technique with a Perkin-Elmer 400 FT-IR/FT-FIR spectrometer. An MPD Mitamura Riken Kogyo (Japan) electrothermal was used to determine the melting points. The nuclear magnetic resonance spectra were carried out on a Bruker Avance III 600 Spectrometer in solution with DMSO- $\mathrm{d}_{6}$ and tetramethylsilane (TMS) as internal standard at $600 \mathrm{MHz}$. The UV-Visible spectra were recorded in $1.0 \times 10^{-4} \mathrm{~mol} \mathrm{~L}^{-1}$ DMSO solution using Shimadzu UV-2600 Spectrophotometer in the range $250-900 \mathrm{~nm}$.

\subsection{Syntheses}

\subsubsection{The Schiff bases syntheses}

$5.0 \mathrm{mmol}$ of the $o$-aminophenol in $10 \mathrm{~mL}$ of ethanol was added in drops to $5.0 \mathrm{mmol}$ of the corresponding salicylaldehyde in $20 \mathrm{~mL}$ of the same solvent. The resulting solution was stirred for $2 \mathrm{~h}$ on addition of three drops of formic acid. The colored solids precipitated were separated by filtration and recrystallized from hot ethanol.

$\mathrm{L}_{1}: \mathrm{R}_{1}=\mathrm{H} ; \mathrm{L}_{2}: \mathrm{R}_{1}=\mathrm{OCH}_{3} ; \mathrm{L}_{3}: \mathrm{R}_{1}=\mathrm{C}_{4} \mathrm{H}_{4}$

Scheme 1. Synthetic route of the Schiff bases.

$\mathrm{L}_{1}\left(\mathrm{C}_{13} \mathrm{H}_{11} \mathrm{NO}_{2}\right)$ : Yield: $97 \%$, orange solid, mol wt: 213.14 , m.pt: $187^{\circ} \mathrm{C}$. Elemental analysis, \% (found) C: $73.25, \mathrm{H}: 5.21, \mathrm{~N}: 6.60$; calculated C:
73.23, H: 5.20, N: 6.57. FT-IR (ATR, $\mathrm{cm}^{-1}$ ): 3746, 3046, 2696, 2533, 1970, 1840, 1627, 1613, 1592, 1529, 1506, 1486, 1459, 1415, 1369, 1309, 1274, 
$1241,1220,1176,1159,1137,1115,1097,1047$, 1019, 967, 945, 902, 853, 806, 763, 741, 725, 630, 572, 547, 525, 475. ${ }^{1} \mathrm{H}$ NMR: $13.78(\mathrm{~s}, 1 \mathrm{H},-\mathrm{OH})$, $9.73(\mathrm{~s}, 1 \mathrm{H},-\mathrm{OH}), 8.92(\mathrm{~s}, 1 \mathrm{H},-\mathrm{HC}=\mathrm{N}), 7.56-6.84$ (m, $8 \mathrm{H}$, aromatic).

$\mathrm{L}_{2}\left(\mathrm{C}_{14} \mathrm{H}_{13} \mathrm{NO}_{3}\right)$ : Yield: 95\%, deep wine solid, mol wt: 243.14 , m.pt: $157^{\circ} \mathrm{C}$. Elemental analysis $\%$ (found) C: 69.10, H: 5.38, N: 5.77; calculated C: 69.12, H: 5.39, N: 5.77. FT-IR $\left(\mathrm{cm}^{-1}\right) 3747,3046$, 2987, 2942, 2896, 2832, 2687, 2561, 2071, 1839, 1626, 1591, 1527, 1494, 1494, 1456, 1437, 1417, $1330,1300,1273,1247,1221,1204,1165,1143$, 1131, 1098, 1039, 941, 931, 869, 854, 811, 787, 738, 663, 589, 566, 549, 516, 499, 479, 471. ${ }^{1} \mathrm{H}$ NMR: 13.07 (s, 1H, $\left.-\mathrm{OH}\right), 9.68(\mathrm{~s}, 1 \mathrm{H},-\mathrm{OH})$, $8.89(\mathrm{~s}, 1 \mathrm{H},-\mathrm{HC}=\mathrm{N}), 7.29-6.82(\mathrm{~m}, 7 \mathrm{H}$, aromatic $)$, $3.71\left(\mathrm{~s}, 3 \mathrm{H},-\mathrm{OCH}_{3}\right)$.

$\mathrm{L}_{3}\left(\mathrm{C}_{17} \mathrm{H}_{13} \mathrm{NO}_{2}\right)$ : Yield: $86 \%$, yellow solid, mol wt: 263.29 , m.pt: $249{ }^{\circ} \mathrm{C}$. Elemental analysis \% (found) C: 77.56, H: 5.00, N: 5.29; calculated, C: 77.55, H: 4.98, N: 5.32. FT-IR $\left(\mathrm{cm}^{-1}\right) 3119,3017$, 2925, 2427, 2175, 1617, 1584, 1547, 1547, 1513,
$1459,1407,1354,1316,1270,1238,1210,1170$, $1140,1114,1039,993,968,920,854,825,774$, 740, 647, 594, 577, 549, 519, 482, 467. ${ }^{1} \mathrm{H}$ NMR: $13.62(\mathrm{~s}, 1 \mathrm{H},-\mathrm{OH}), 10.31(\mathrm{~s}, 1 \mathrm{H},-\mathrm{OH}), 9.47(\mathrm{~s}$, $1 \mathrm{H},-\mathrm{HC}=\mathrm{N}), 8.34-6.70(\mathrm{~m}, 10 \mathrm{H}$, aromatic $)$

\subsubsection{Synthesis of the mixed-ligand complexes}

A methanolic solution of $\mathrm{Ni}\left(\mathrm{CH}_{3} \mathrm{COO}\right)_{2} \cdot 4 \mathrm{H}_{2} \mathrm{O}$ $(5.0 \mathrm{mmol})$ was added in drops to the corresponding Schiff base solution $(5.0 \mathrm{mmol})$ while stirring in $10 \mathrm{ml}$ of the same solvent. Some drops of anhydrous ammonia were added to modify the $\mathrm{pH}$ of the resulting mixture to 7-7.5 and refluxed at $60{ }^{\circ} \mathrm{C}$ for $3 \mathrm{~h}$. The colored solids precipitated were filtered by vacuum filtration, washed with distilled water, diethyl ether and methanol. These were dried over silica gel in a desiccator for two days and recrystallized from DMSO.

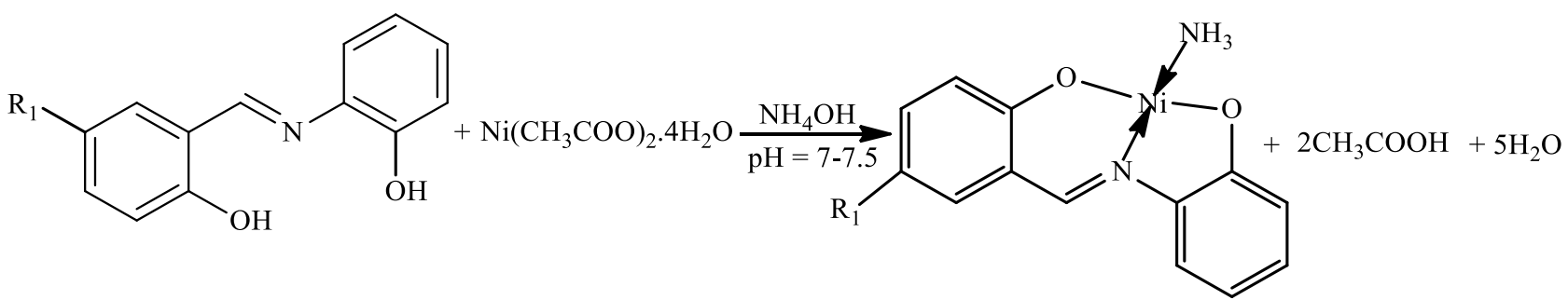

Scheme 2. Synthetic route of the Ni(II) mixed-ligand complexes.

$\mathrm{NiL}_{1} \mathrm{NH}_{3}\left(\mathrm{C}_{13} \mathrm{H}_{12} \mathrm{~N}_{2} \mathrm{O}_{2} \mathrm{Ni}\right)$ : Yield: $85 \%$, wine solid, mol wt.: 286.94 . m.pt: $>260{ }^{\circ} \mathrm{C}$. Elemental analysis \% (found) $\mathrm{C}: 54.44, \mathrm{H}: 4.23, \mathrm{~N}: 9.78$; calculated C: 54.42, H: 4.22, N: 9.76. FT-IR (ATR, $\left.\mathrm{cm}^{-1}\right)$ : 3336, 3276, 3235, 3158, 3040, 3016, 2685, 2591, 2541, 2323, 2098, 1916, 1880, 1843, 1802, $1760,1689,1602,1580,1526,1479,1468,1441$, $1375,1358,1322,1313,1303,1283,1263,1225$, $1172,1156,1143,1130,1111,1029,960,941,926$, $941,926,875,840,796,772,750,743,730,695$, 657, 614, 568, 546, 524, 484, 461. ${ }^{1} \mathrm{H}$ NMR $\left(\right.$ DMSO- $\left._{6}, \delta, \mathrm{ppm}\right): 8.79(\mathrm{~s}, 1 \mathrm{H},-\mathrm{HC}=\mathrm{N}), 7.75-$ $6.46\left(\mathrm{~m}, 8 \mathrm{H}\right.$, aromatic), $2.37\left(\mathrm{~s}, 3 \mathrm{H},-\mathrm{NH}_{3}\right) .{ }^{13} \mathrm{C}$ NMR (DMSO-d $\left.\mathrm{d}_{6}, \delta, \mathrm{ppm}\right): 167.43,162.96,148.06$, $139.55,135.52,134.04,129.09,120.83,118.51$, $116.56,115.44,114.75$.

$\mathrm{NiL}_{2} \mathrm{NH}_{3}\left(\mathrm{C}_{14} \mathrm{H}_{14} \mathrm{~N}_{2} \mathrm{O}_{3} \mathrm{Ni}\right)$ : Yield: $82 \%$, wine solid, mol wt.: 316.97 , m.pt: $>260{ }^{\circ} \mathrm{C}$. Elemental analysis, \% (found) $\mathrm{C}: 53.10, \mathrm{H}: 4.47, \mathrm{~N}$ : 8.85; calculated C: $53.05, \mathrm{H}: 4.45, \mathrm{~N}: 8.84$. FT-IR $\left(\mathrm{cm}^{-1}\right): 3341,3236,3159,2935,2832,2009,1840$, $1601,1584,1529,1477,1445,1424,1367,1314$, $1302,1282,1257,1238,1212,1177,1147,1111$, $1049,1031,952,939,898,871,846,821,804,750$, 994, 658, 643, 582, 567, 550, 522 503, 487, 474, 464, 456. ${ }^{1} \mathrm{H}$ NMR (DMSO-d $\left.{ }_{6}, \delta, \mathrm{ppm}\right): 8.65$ (s, $1 \mathrm{H}$, $-\mathrm{HC}=\mathrm{N}), 7.71-6.45(\mathrm{~m}, 7 \mathrm{H}$, aromatic), $3.69(\mathrm{~s}, 3 \mathrm{H}$, $\left.-\mathrm{OCH}_{3}\right), 2.25\left(\mathrm{~s}, 3 \mathrm{H},-\mathrm{NH}_{3}\right) .{ }^{13} \mathrm{C}$ NMR (DMSO-d 6 , $\delta, \mathrm{ppm}): 167.39,158.49,149.25,147.55,139.62$, $129.15,124.40,121.55,120.98,118.56,116.34$, 114.79, 56.44 .

$\mathrm{NiL}_{3} \mathrm{NH}_{3}\left(\mathrm{C}_{17} \mathrm{H}_{14} \mathrm{~N}_{2} \mathrm{O}_{2} \mathrm{Ni}\right)$ : Yield: $84 \%$, brown solid, mol wt.: 337 , m.pt: $>260{ }^{\circ} \mathrm{C}$. Elemental analysis \% (found) C: 60.71, H: 4.09, N: 8.27; calculated C: $60.59, \mathrm{H}: 4.19, \mathrm{~N}: 8.31$. FT-IR $\left(\mathrm{cm}^{-1}\right)$ : $3340,3239,3163,3038,2338,2148,1613,1600$, $1578,1533,1509,1476,1457,1428,1397,1361$, $1344,1314,1297,1280,1262,1252,1205,1171$, $1145,1111,1041,1029,986,963,912,835,817$, $775,757,693,670,653,587,563,508,470,457$. 
${ }^{1} \mathrm{H} \quad \mathrm{NMR}$ (DMSO-d $\left.6, \delta, \quad \mathrm{ppm}\right): 9.25 \quad(\mathrm{~s}, 1 \mathrm{H}$, $-\mathrm{HC}=\mathrm{N}), 8.49-6.30(\mathrm{~m}, 10 \mathrm{H}$, aromatic), $2.37(\mathrm{~s}$, $\left.3 \mathrm{H},-\mathrm{NH}_{3}\right) .{ }^{13} \mathrm{C}$ NMR (DMSO-d $\left.6, \delta, \mathrm{ppm}\right): 167.18$, $163.60,141.43,140.48,134.85,134.39,129.17$, $128.80,128.01,127.12,124.19,123.06,121.66$, 118.36, 116.78, 114.89, 111.71 .

\subsection{Antibacterial study}

The antibacterial potentials of the compounds were measured against some Gram-positive and Gram-negative bacterial strains by agar-well diffusion method. The Gram-positive bacterial strains were Streptococcus agalactiae and Staphylococcus aureus while Escherichia coli, Klebsiella pneumoniae, Proteus mirabilis, Pseudomonas aeruginosa and Salmonella typhimurium were the Gram-negative bacterial strains used. The nutrient agar medium was used to sub-culture the isolates of bacterial strains which were nurtured at $37{ }^{\circ} \mathrm{C}$ for 24 h. $20 \mathrm{~mL}$ of disinfected nutrient agar medium was dispensed in each germfree Petri dish after modifying the bacterial strains cultures to 0.5 McFarland standards, these were allowed to gel. The dishes were swabbed with the inoculum of the bacterial strains and left for $15 \mathrm{~min}$ to adsorb unto the gel. Varying concentrations of the samples $(5,10$ and $15 \mathrm{mg} \mathrm{mL}^{-1}$ ) were filled into the wells that were drilled on the seeded agar dishes by a sterile cork borer of $6 \mathrm{~mm}$ diameter. These were kept for $1 \mathrm{~h}$ in the refrigerator to allow for thorough circulation of the samples into the medium and then nurtured for $24 \mathrm{~h}$ at $37{ }^{\circ} \mathrm{C}$ observing the inhibition zones. Antimicrobial activities were expressed as inhibition diameter zones in millimeter $(\mathrm{mm})$. Standard Gentamycin $\left(10 \mu \mathrm{g} \mathrm{mL}^{-1}\right)$ was employed as control $\mathbf{l}^{17,20,21}$.

\subsection{Phosphomolybdate total antioxidant capacity (PTAC) assay}

The total antioxidant capacities (TAC) of the compounds were determined by phosphomolybdenum assay and ascorbic acid was used as the standard. $1.0 \mathrm{~mL}$ of reagent $\left(0.6 \mathrm{~mol} \mathrm{~L}^{-1}\right.$ sulfuric acid, $28 \mu \mathrm{mol} \mathrm{L}^{-1}$ sodium phosphate and $4 \mu \mathrm{mol} \mathrm{L} \mathrm{L}^{-1}$ ammonium molybdate) was reacted with a fractional part of the extract solution $(1.0 \mathrm{~mL}$ of $1000 \mu \mathrm{g}$ ). The covered tubes were incubated at $95^{\circ} \mathrm{C}$ in a water bath for $90 \mathrm{~min}$ after which the samples were cooled to room temperature and a UV spectrophotometer was used to measure the absorbance of the aqueous solution of each at $695 \mathrm{~nm}$. The procedure was repeated for an empty solution containing $1.0 \mathrm{~mL}$ of reagent solution. The TAC studies were performed three times and the mean was expressed as equivalents of ascorbic $\operatorname{acid}^{22}$

\subsection{Computational method}

The Ni(II) complexes were modeled and optimized using Gaussian 9 and Spartan 14 computational software packages which were implemented on an Intel Core i3-3100M computer. They were modeled based on the electronic spectra and elemental analyses data. Density functional theory (DFT) was employed for the geometry optimization, chemical shifts, electronic transitions and frequency calculations of the complexes. The DFT calculations were performed on the optimized geometry in the ground state using Becke's threeparameter hybrid functional employing the LeeYang-Parr correlation functional (B3LYP) and the Empirical Density Functional 1 methods (EDF1) with $6-31 \mathrm{G}^{* *}$ basis $\operatorname{set}^{23-26}$.

\section{Results and discussion}

The Schiff base ligands and the mixed-ligand complexes were stable and colored solids. The complexes were not soluble in water and almost all organic solvents except in DMSO and DMF. The mixed-ligand complexes have higher melting points than the parent Schiff base ligands, this showed that they have better stability than the Schiff bases. Elemental analyses data indicated the formation of 1:1:1 [nickel:Schiff base:ammonia] molar ratio for the mixed-ligand complexes. The crystals obtained in DMSO were not suitable for Xray diffraction measurement. No crystal was obtained in DMF. Attempts to isolate single crystal suitable for X-ray diffraction measurement were not successful.

\subsection{Spectroscopic studies}

\subsubsection{FT-IR spectra}

The spectra of the free Schiff base ligands $\left(\mathrm{L}_{1}\right.$, $\mathrm{L}_{2}$ and $\left.\mathrm{L}_{3}\right)$ showed the azomethine, $\mathrm{v}(-\mathrm{HC}=\mathrm{N})$ bands at 1627,1617 and $1626 \mathrm{~cm}^{-1}$ respectively, these bands shifted to lower wavenumbers (1601$1600 \mathrm{~cm}^{-1}$ ) in the mixed-ligand complexes (Figs. 13). This revealed the involvements of the 
azomethine nitrogen atoms in coordination with the $\mathrm{Ni}$ (II) ions and the formation of metal-ligand bonds. The bands at 1274, 1228 and $1247 \mathrm{~cm}^{-1}$ in the spectra of the free Schiff base ligands were assigned to the phenolic $\mathrm{C}-\mathrm{O}$ stretching vibrations of $\mathrm{L}_{1}, \mathrm{~L}_{2}$ and $\mathrm{L}_{3}$ respectively. These bands shifted to higher wave numbers at $1301-1261 \mathrm{~cm}^{-1}$ in the complexes, these showed the participation of the oxygen atoms of phenolic groups in coordination with the Ni(II) ions. The free Schiff bases $\left(\mathrm{L}_{1}, \mathrm{~L}_{2}\right.$ and $\mathrm{L}_{3}$ ) exhibited hydroxyl $\mathrm{v}(\mathrm{O}-\mathrm{H})$ absorption bands at 3746, 3747 and 3119-2427 $\mathrm{cm}^{-1}$ respectively, these bands were absent in the complexes which further confirmed the deprotonation of the phenolic groups and coordination of oxygen to the $\mathrm{Ni}(\mathrm{II})$ ion $^{8,12,27}$. The complexes showed new bands at 3336, 3340 and
$3340 \mathrm{~cm}^{-1}$ respectively assigned to $\mathrm{r}(\mathrm{N}-\mathrm{H})$ stretching vibrations of ammonia $\left(-\mathrm{NH}_{3}\right)$ groups, these indicated the presence of $-\mathrm{NH}_{3}$ groups in the complexes $^{28}$. The complexes displayed the aromatic $\mathrm{v}(\mathrm{C}-\mathrm{H})$ and $\mathrm{r}(\mathrm{C}=\mathrm{C})$ absorption bands around 3276-3016 and 1584-1400 $\mathrm{cm}^{-1}$ respectively. The aromatic $\mathrm{v}(\mathrm{C}-\mathrm{H})$ bending vibrations appeared around 875-647 $\mathrm{cm}^{-1}$. The bands around 485-471 and 550-508 $\mathrm{cm}^{-1}$ in the complexes were assigned to the stretching vibrations of the nickel-oxygen, $\mathrm{r}(\mathrm{Ni}-\mathrm{O})$ and nickel-nitrogen, $\quad \mathrm{r}(\mathrm{Ni}-\mathrm{N})$ respectively. These confirmed the attachment of the Schiff bases to the central nickel ion through the phenolic oxygen atoms and the azomethine nitrogen atoms ${ }^{8,11,17}$. 


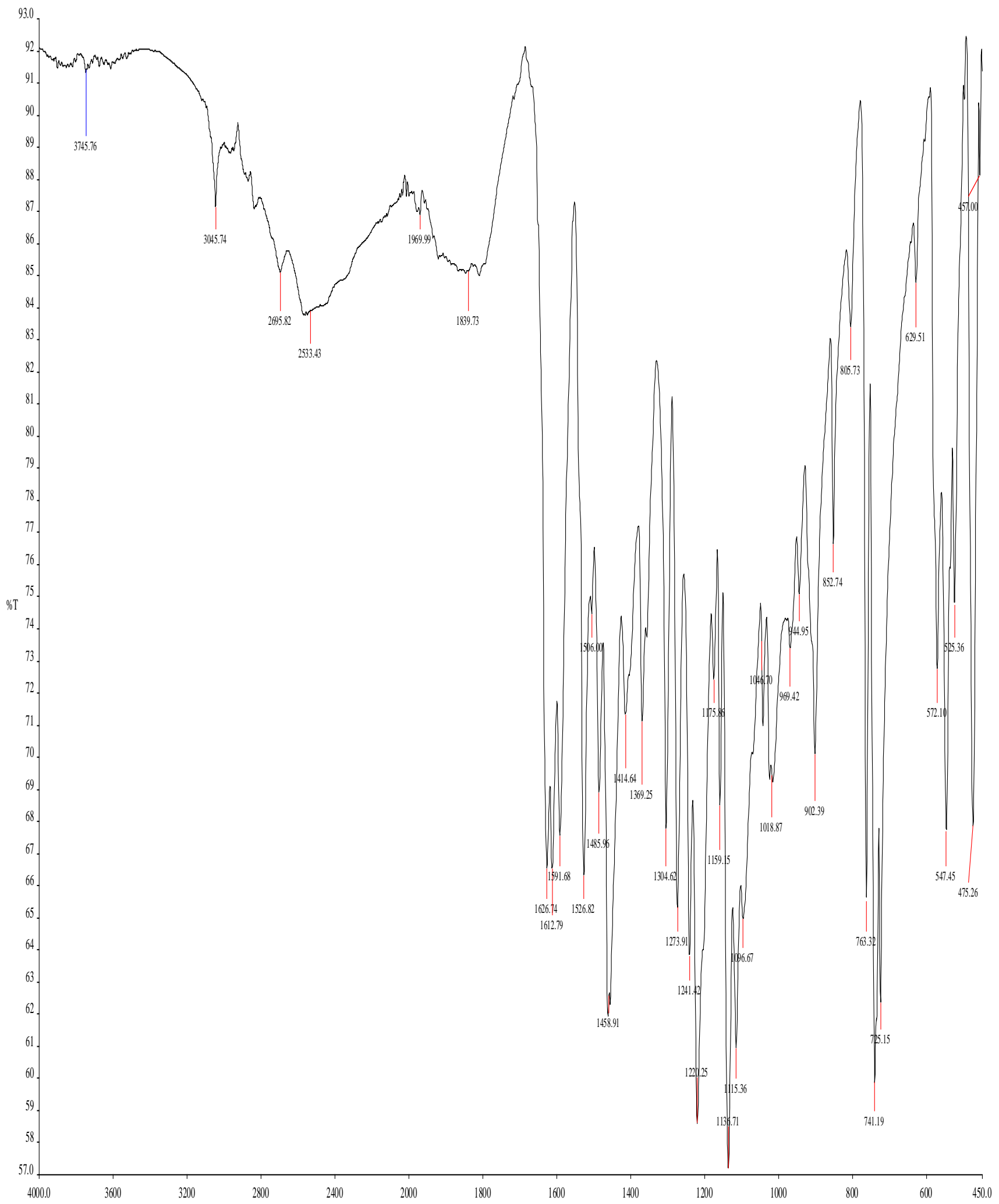

(A) 


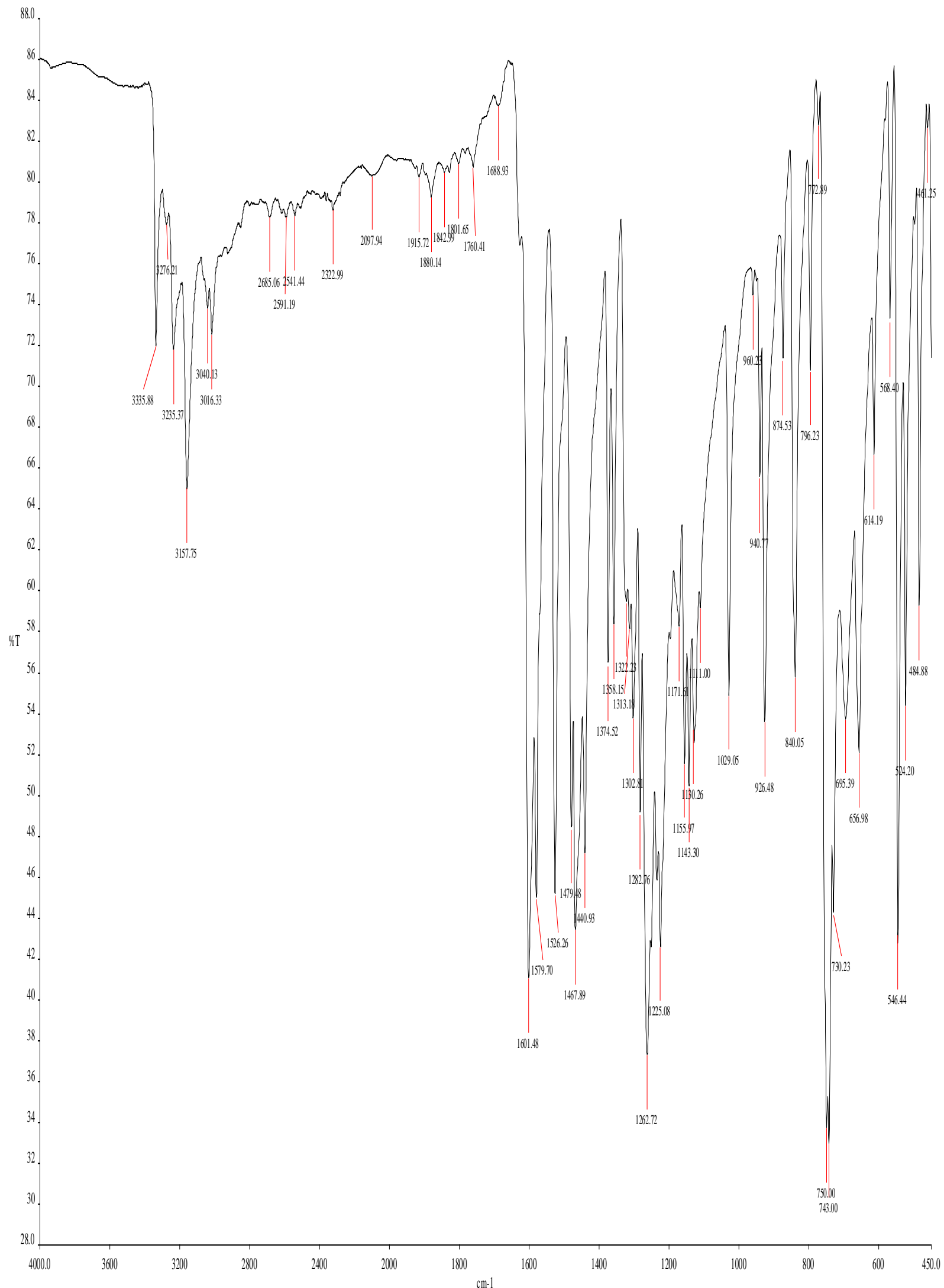

(B)

Figure 1. IR spectra of $\mathrm{L}_{1}(\mathrm{~A})$ and $\mathrm{NiL}_{1} \mathrm{NH}_{3}(\mathrm{~B})$. 


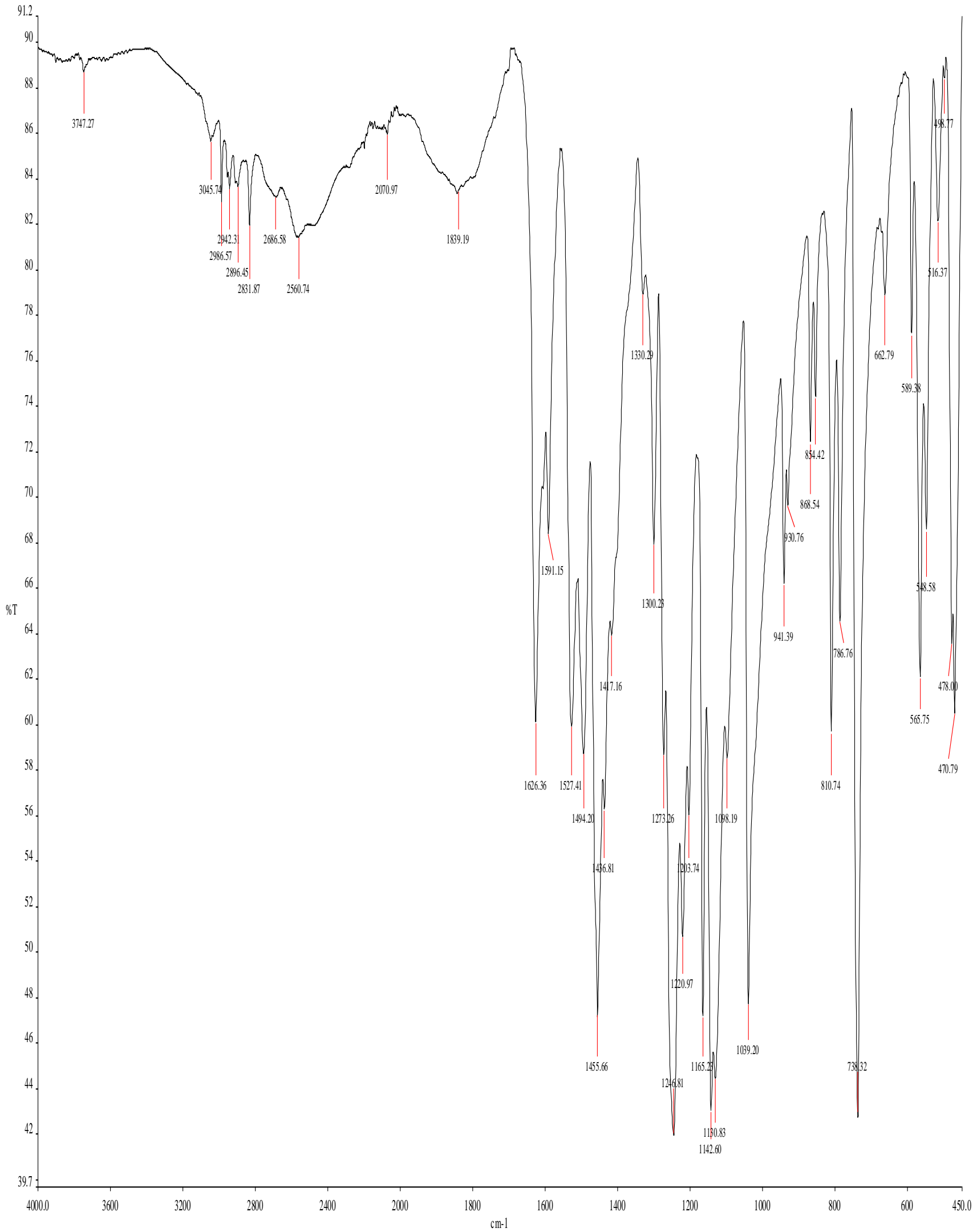

(A) 


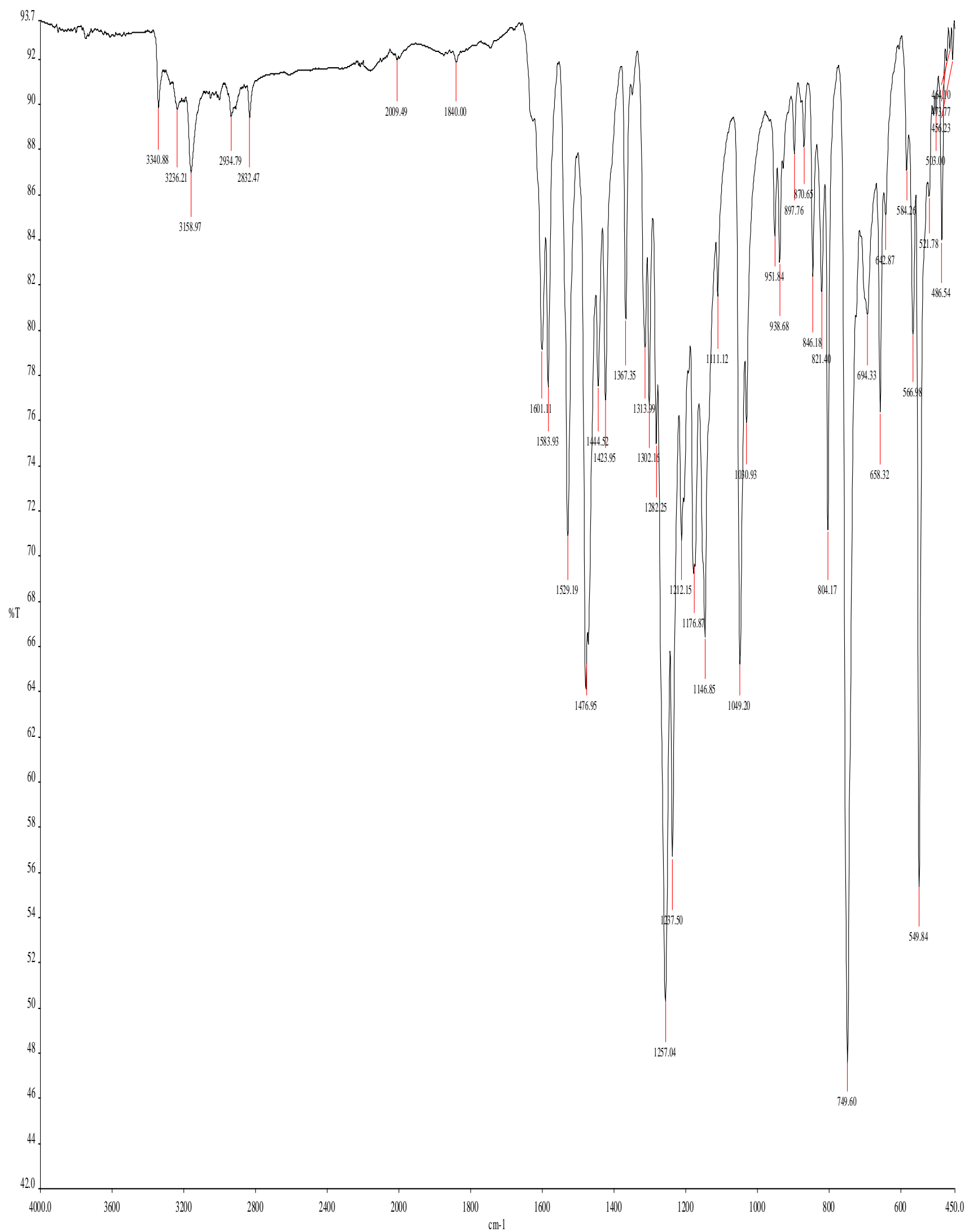

(B)

Figure 2. IR spectra of $\mathrm{L}_{2}(\mathrm{~A})$ and $\mathrm{NiL}_{2} \mathrm{NH}_{3}(\mathrm{~B})$. 


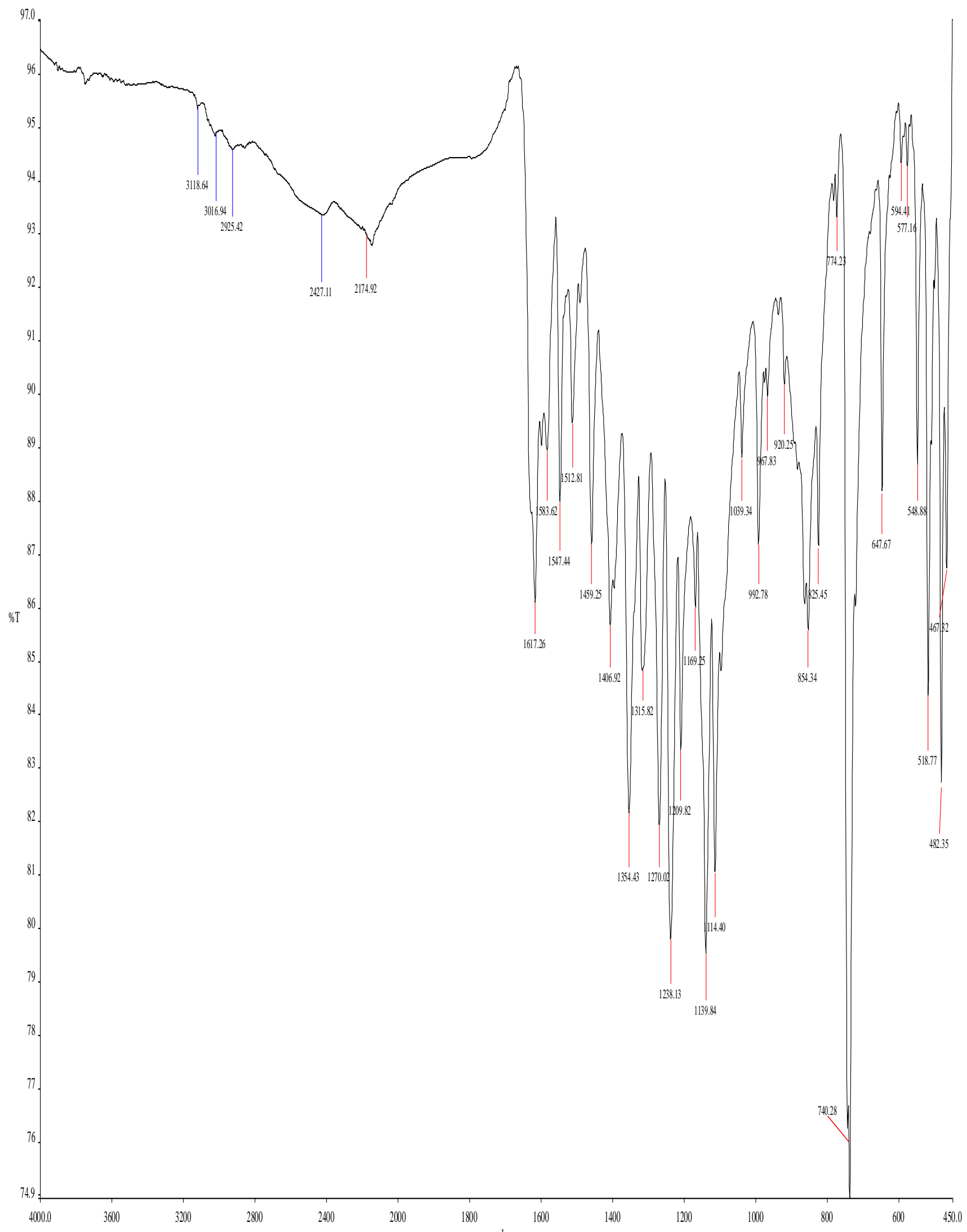

(A) 


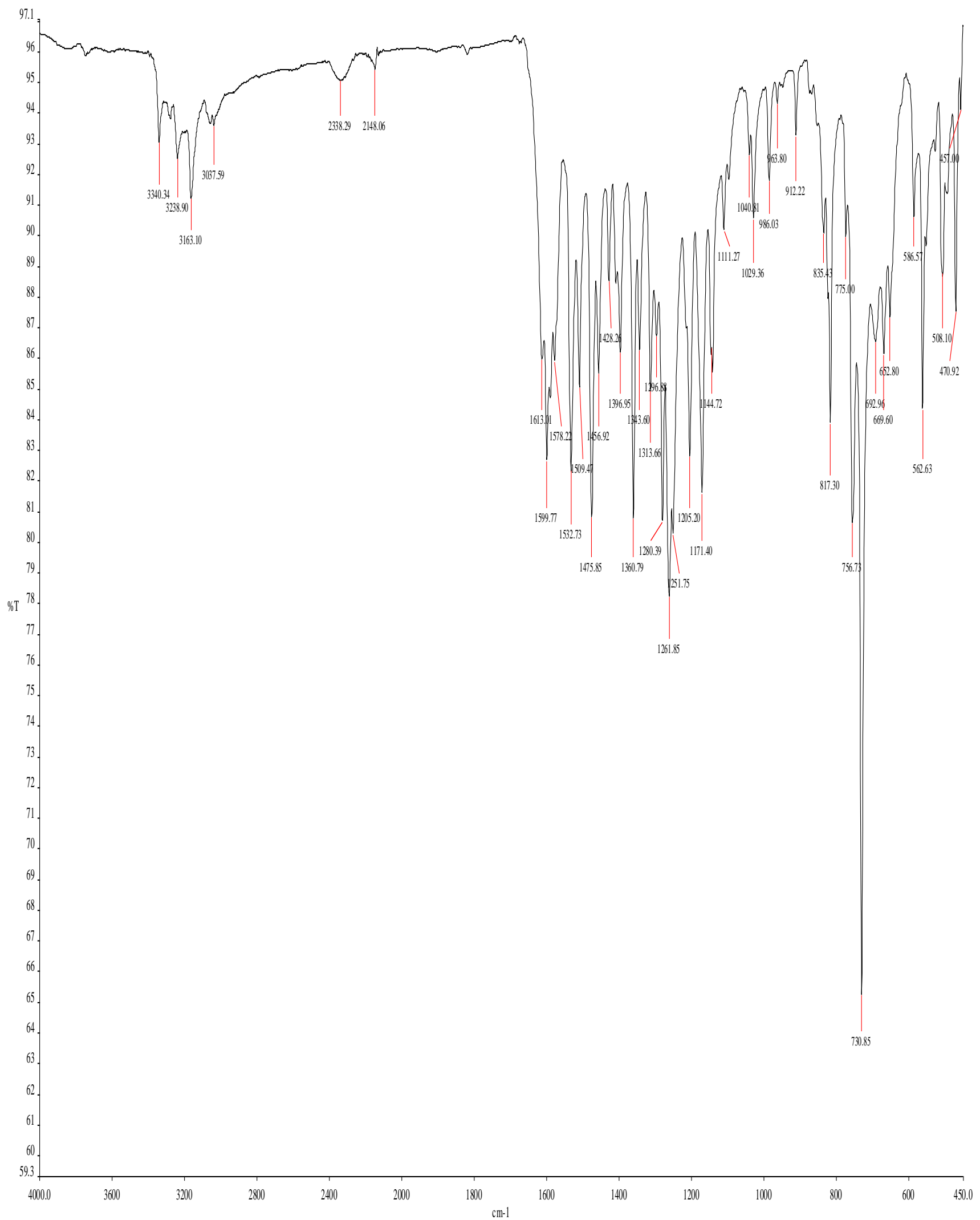

(B)

Figure 3. IR spectra of $\mathrm{L}_{3}(\mathrm{~A})$ and $\mathrm{NiL}_{3} \mathrm{NH}_{3}(\mathrm{~B})$. 


\subsubsection{NMR spectra}

The ${ }^{1} \mathrm{H}$ NMR spectra of the free Schiff bases showed two singlet signals at $\delta 13.78-13.07$ and $\delta$ $10.31-9.68 \mathrm{ppm}$ which were assigned to the two phenolic $-\mathrm{OH}$ protons. The spectra showed singlet signals at $\delta 8.92\left(\mathrm{~L}_{1}\right), 8.89\left(\mathrm{~L}_{2}\right)$ and $9.47 \mathrm{ppm}\left(\mathrm{L}_{3}\right)$ attributed to the azomethine $(-\mathrm{HC}=\mathrm{N})$ protons. The aromatic protons appeared as multiplets around $\delta$ 8.34-6.70 $\mathrm{ppm}^{8,11,27}$. The three protons of the methoxy $\left(-\mathrm{OCH}_{3}\right)$ groups in ' $\mathrm{L}_{2}$ ' appeared as a sharp singlet signal at $\delta 3.71 \mathrm{ppm}^{29,30}$. A comparison of the ${ }^{1} \mathrm{H}$ NMR spectra of the free Schiff base ligands with the Ni(II) mixed-ligand complexes (Figs. 4-6) showed that the chemical shifts for the $-\mathrm{OH}$ protons in the free Schiff bases were not observed in the spectra of the complexes. The absence of the $-\mathrm{OH}$ signals indicated the deprotonation of the hydroxyl groups of the Schiff bases prior to coordination with $\mathrm{Ni}(\mathrm{II})$ ion. It also confirmed the bonding of oxygen to the $\mathrm{Ni}(\mathrm{II})$ ions. Moreover, the coordination of the azomethine nitrogen atoms of the Schiff bases to $\mathrm{Ni}(\mathrm{II})$ ion were indicated by the displacements of the chemical shifts of the azomethine hydrogen to upfield region at $\delta 9.25-8.65 \mathrm{ppm}$. The aromatic protons appeared as multiplets around $\delta 8.49-6.30$ ppm for the complexes ${ }^{8,11,27}$. The new singlet signals at $\delta 2.37$ and $\delta 2.25 \mathrm{ppm}$ in the Ni(II) complexes were assigned to the three hydrogen atoms of $-\mathrm{NH}_{3}$ groups ${ }^{28}$. The appearance of these new singlet signals confirmed the presence of ammonia in the complexes as they are not present in the free Schiff base ligands. Furthermore, the three hydrogen atoms of the new singlet signals in the complexes spectra showed that the complex containing $\mathrm{NH}_{3}$ is not in the form of ammonium ion $\left(\mathrm{NH}_{4}{ }^{+}\right)$. The three $-\mathrm{OCH}_{3}$ group protons of ' $\mathrm{L}_{2}$ ' in the $\mathrm{Ni}(\mathrm{II})$ complex appeared as sharp singlet signals at $\delta 3.69 \mathrm{ppm}^{29,31}$. Signals at $3.33 \mathrm{ppm}$ and 2.45-2.50 ppm are for $\mathrm{H}_{2} \mathrm{O} / \mathrm{DMSO}$ and DMSO respectively in all the spectra.

The ${ }^{13} \mathrm{C}$ NMR spectra (Figs. S1-S3, supplementary data) are consistent with the proton NMR of the complexes. The ${ }^{13} \mathrm{C}$ NMR spectrum of $\mathrm{NiL}_{1} \mathrm{NH}_{3}$ showed a peak at $\delta 167.43 \mathrm{ppm}$ which confirmed the presence of azomethine carbon in the complex. The aromatic carbons peaks appeared in the range 162.96-114.75 ppm ${ }^{8,11,27}$. In $\mathrm{NiL}_{2} \mathrm{NH}_{3}$ ${ }^{13} \mathrm{C}$ NMR spectrum, the azomethine carbon appeared at $167.38 \mathrm{ppm}$ and the aromatic carbons peaks appeared in the range 156.48-114.77 ppm while the carbon peak for $-\mathrm{OCH}_{3}$ group appeared at $\delta 55.96 \mathrm{ppm}^{29,30}$. $\mathrm{NiL}_{3} \mathrm{NH}_{3}{ }^{13} \mathrm{C}$ NMR spectrum showed the azomethine carbon peak at $167.17 \mathrm{ppm}$ and the aromatic carbons peaks in the range $163.59-111.70 \mathrm{ppm}^{17}$.

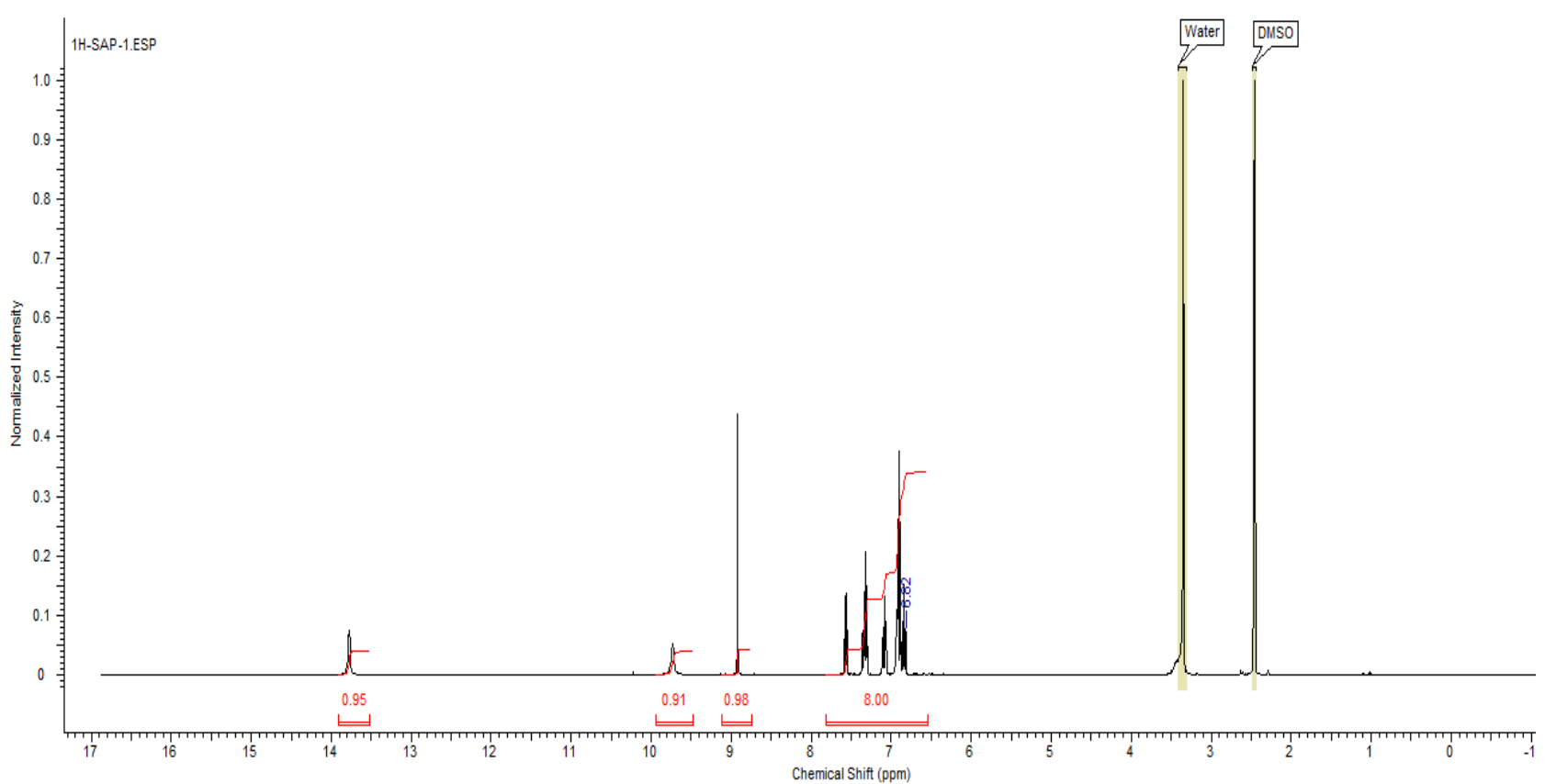

(A) 


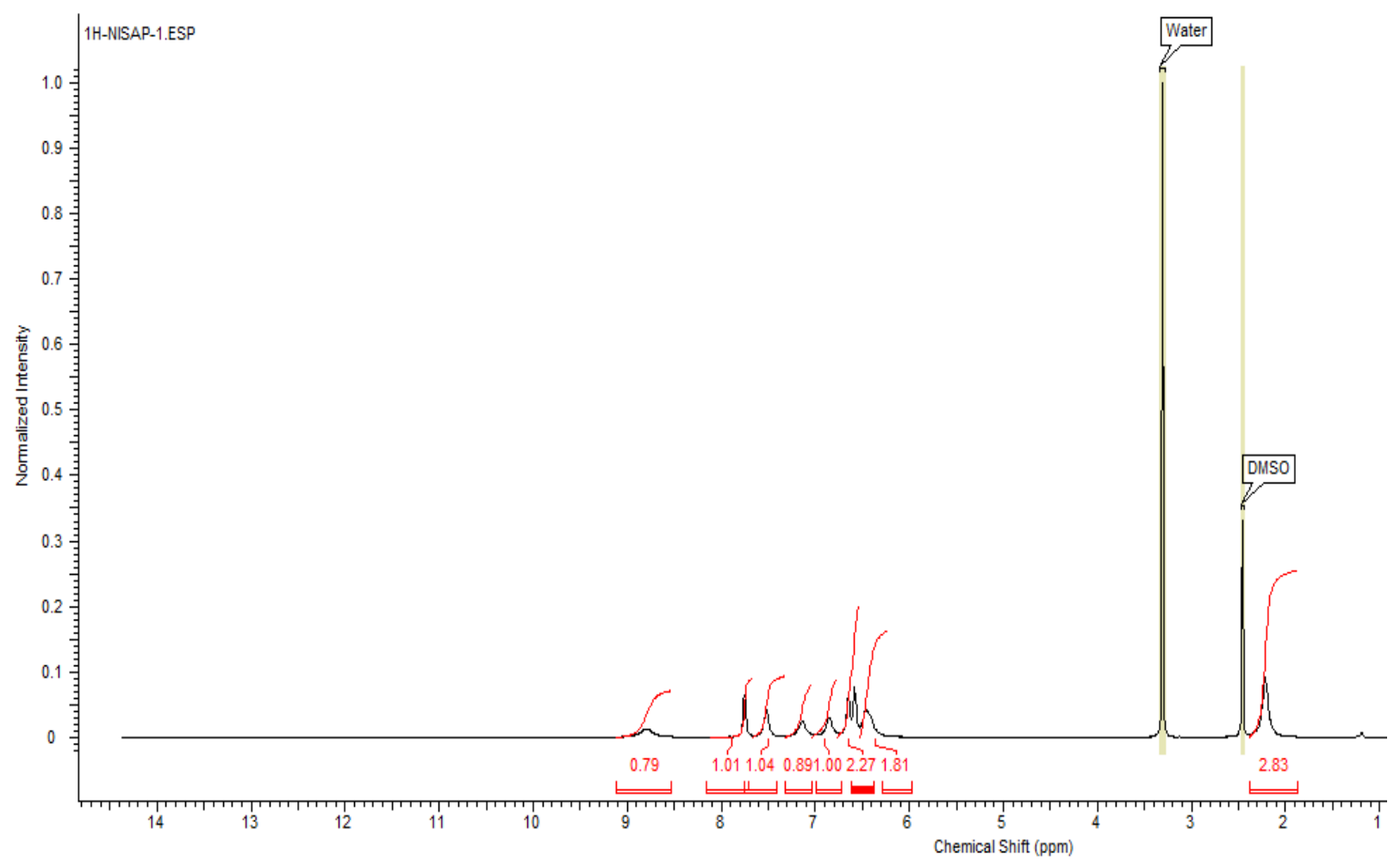

(B)

Figure 4. ${ }^{1} \mathrm{H}$ NMR spectra of $\mathrm{L}_{1}(\mathrm{~A}), \mathrm{NiL}_{1} \mathrm{NH}_{3}(\mathrm{~B})$ in water and DMSO.

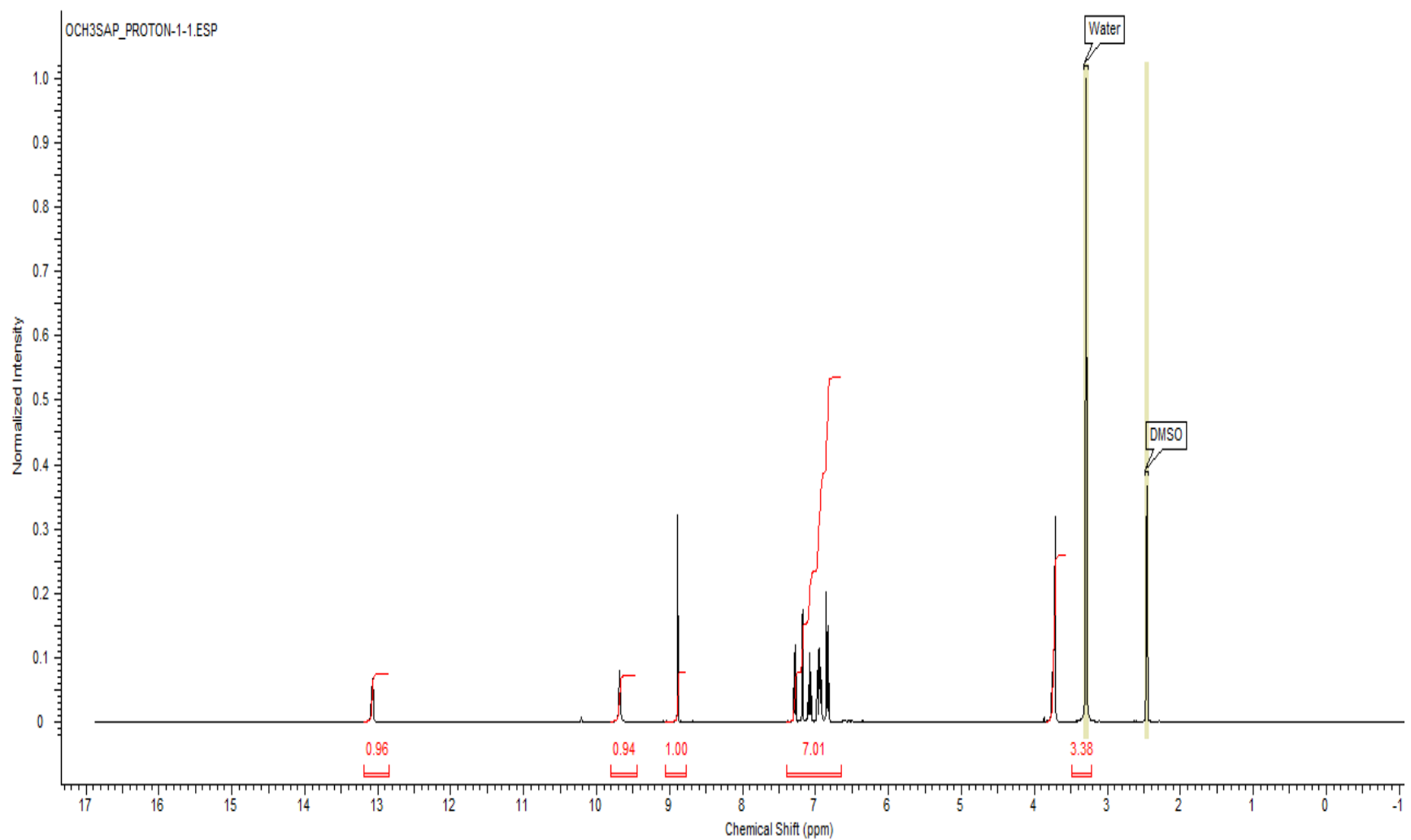

(A) 


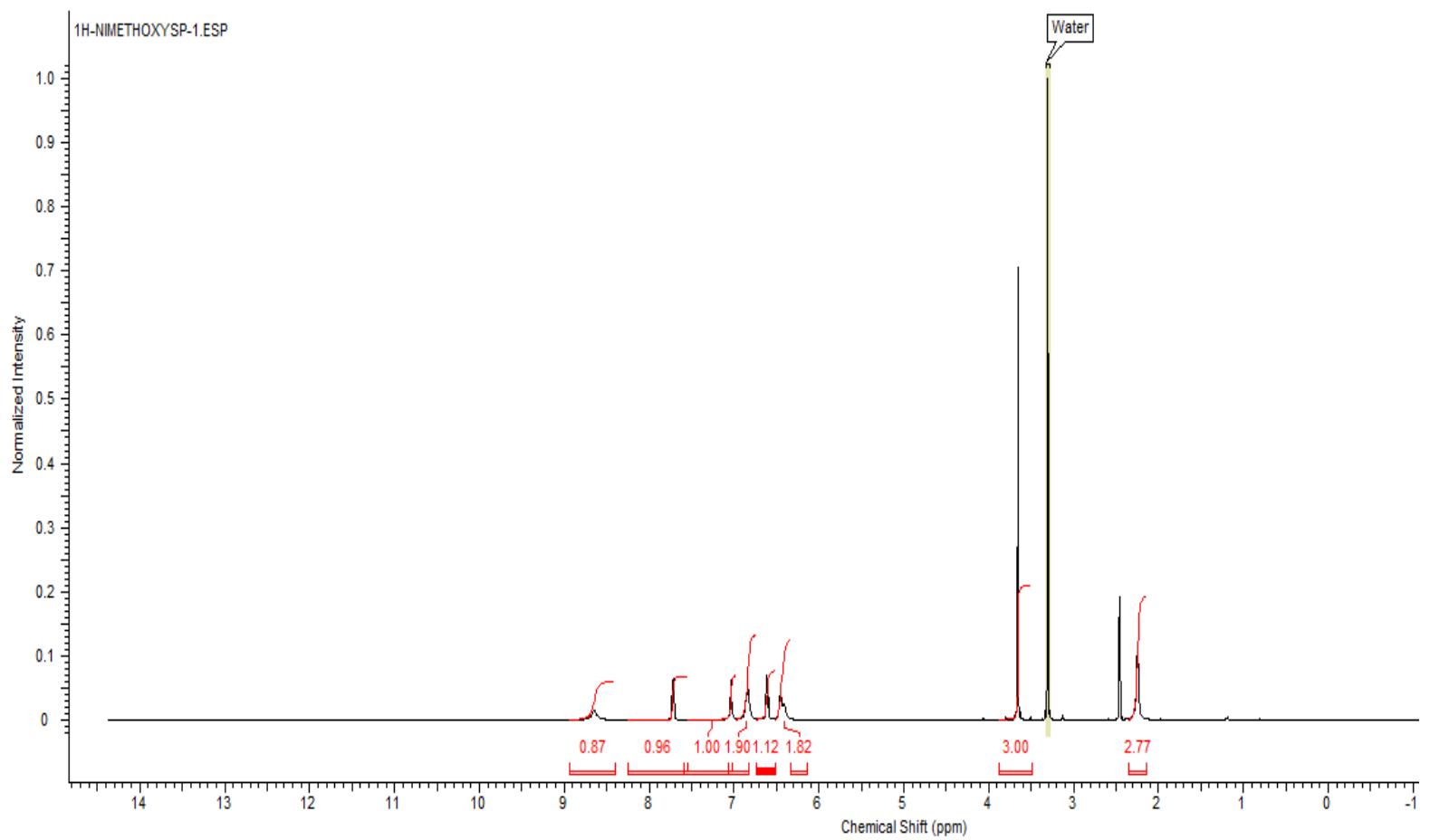

(B)

Figure 5. ${ }^{1} \mathrm{H}$ NMR spectra of $\mathrm{L}_{2}(\mathrm{~A}), \mathrm{NiL}_{2} \mathrm{NH}_{3}(\mathrm{~B})$ in water and DMSO.

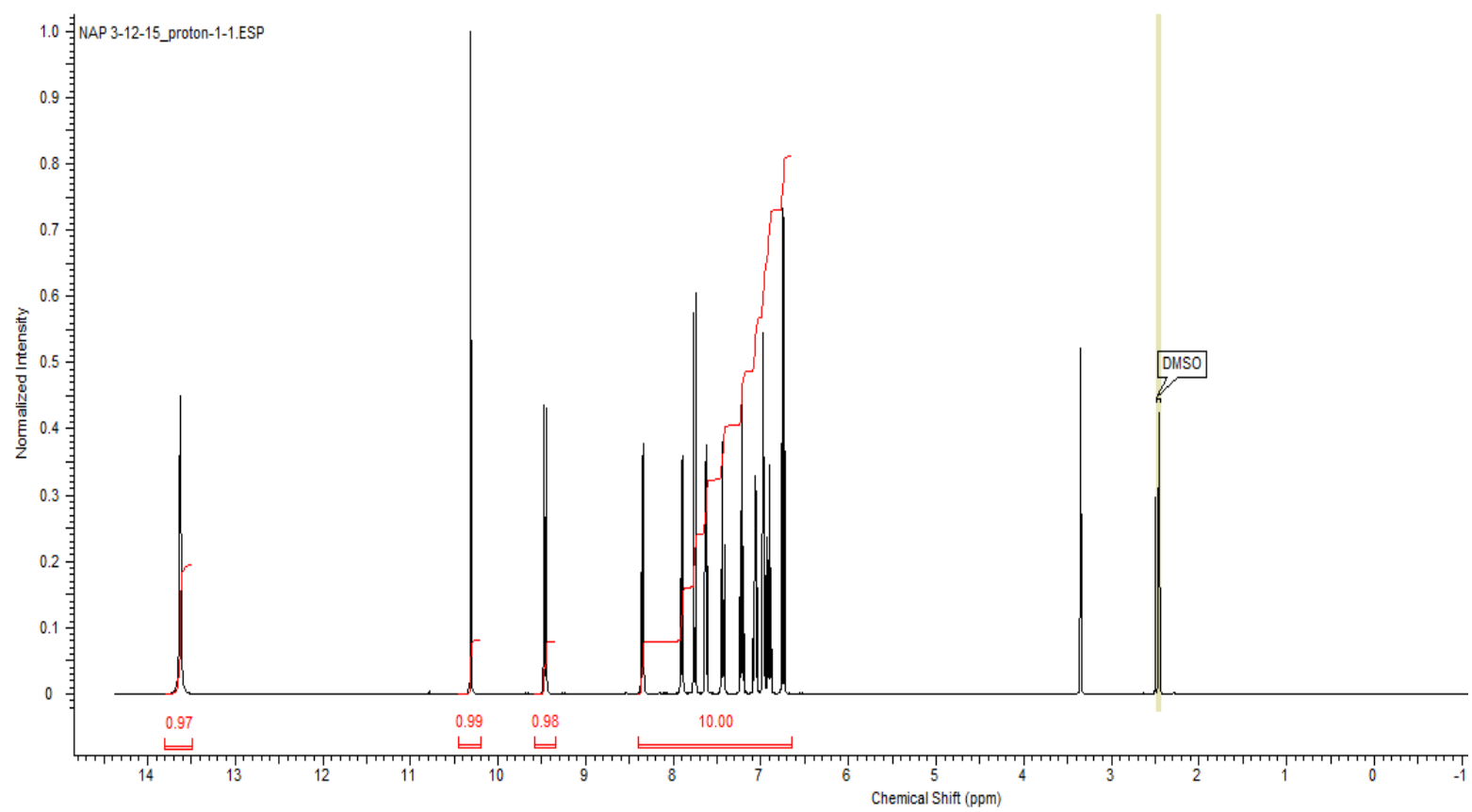

(A) 


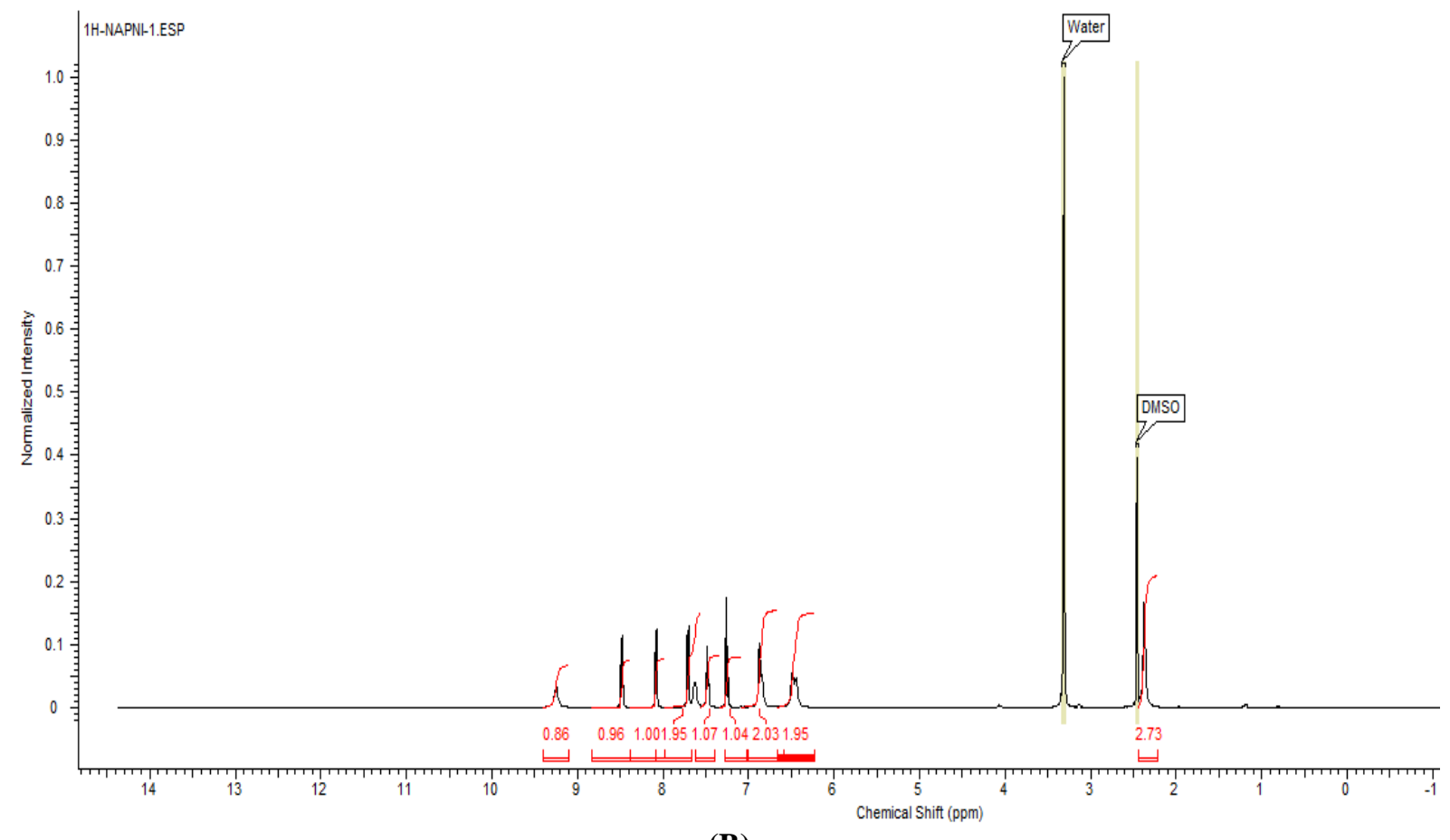

(B)

Figure 6. ${ }^{1} \mathrm{H}$ NMR spectra of $\mathrm{L}_{3}(\mathrm{~A})$ and $\mathrm{NiL}_{3} \mathrm{NH}_{3}(\mathrm{~B})$ in water and DMSO.

\subsubsection{Electronic spectra}

The electronic spectra data of the Schiff bases and the $\mathrm{Ni}$ (II) mixed-ligand complexes are presented in Table 1. The spectra were recorded in $1.0 \times$ $10^{-4} \mathrm{~mol} \mathrm{~L}^{-1}$ DMSO solution in the range 250 $900 \mathrm{~nm}$. The spectra of the Schiff bases showed absorption bands around 30769-27027 $\mathrm{cm}^{-1}$ and $22279-21186 \mathrm{~cm}^{-1}$ which were assigned to $\pi \rightarrow \pi^{*}$ and $\mathrm{n} \rightarrow \pi^{*}$ transitions respectively ${ }^{17,29,31}$. These transitions were observed in the spectra of the mixed-ligand complexes (Figs. 7-9) but some shifted to longer wavelength, confirming the coordination of the Schiff base ligands to the Ni(II) ion. The electronic spectrum of $\mathrm{NiL}_{1} \mathrm{NH}_{3}$ displayed two absorption bands at 33113 and $23529 \mathrm{~cm}^{-1}$ which were assigned to $\pi \rightarrow \pi^{*}$ and ${ }^{1} \mathrm{~A}_{1 \mathrm{~g}} \rightarrow{ }^{1} \mathrm{E}_{1 \mathrm{~g}}$ transitions respectively. Similarly, $\mathrm{NiL}_{2} \mathrm{NH}_{3}$ spectrum showed two absorption bands at 32573 and $22779 \mathrm{~cm}^{-1}$ assigned to $\pi \rightarrow \pi^{*}$ and ${ }^{1} \mathrm{~A}_{1 \mathrm{~g}} \rightarrow{ }^{1} \mathrm{E}_{1 \mathrm{~g}}$ transitions respectively ${ }^{30}$. However, $\mathrm{NiL}_{3} \mathrm{NH}_{3}$ showed three absorption bands at 31250, 22472 and $21186 \mathrm{~cm}^{-1}$ assigned to $\pi \rightarrow \pi^{*},{ }^{1} \mathrm{~A}_{1 \mathrm{~g}} \rightarrow{ }^{1} \mathrm{E}_{1 \mathrm{~g}}$, ${ }^{1} \mathrm{~A}_{1 \mathrm{~g}} \rightarrow{ }^{1} \mathrm{~B}_{1 \mathrm{~g}}$ transitions respectively ${ }^{28}$. The absence of any band below $10000 \mathrm{~cm}^{-1}$ eliminated the possibility of tetrahedral geometry ${ }^{8}$. Hence, this suggest a square planar geometry. 
Table 1. Experimental and theoretical electronic spectra data of the compounds.

\begin{tabular}{|l|l|l|}
\hline Compounds & Bands in $\mathbf{c m}^{-1}$ & Assignments \\
\hline $\mathrm{L}_{1}$ & 28329 & $\pi \rightarrow \pi^{*}$ \\
$\mathrm{NiL}_{1} \mathrm{NH}_{3}$ (Exp) & 33113,23529 & $\pi \rightarrow \pi^{*},{ }_{1 \mathrm{~g}} \mathrm{~A}_{1 \mathrm{~g}}{ }^{1} \mathrm{E}_{1 \mathrm{~g}}$, \\
$\mathrm{NiL}_{1} \mathrm{NH}_{3}$ (B3LYP) & $2317,22422,19377$ & \\
$\mathrm{NiL}_{1} \mathrm{NH}_{3}$ (EDF1) & 22382,15290 & $\pi \rightarrow \pi^{*}$ \\
\hline $\mathrm{L}_{2}$ & 27027 & $\pi \rightarrow \pi^{*},{ }^{1} \mathrm{~A}_{1 \mathrm{~g}} \rightarrow{ }^{1} \mathrm{E}_{1 \mathrm{~g}}$, \\
$\mathrm{NiL}_{2} \mathrm{NH}_{3}$ (Exp) & 32573,22779 & \\
$\mathrm{NiL}_{2} \mathrm{NH}_{3}$ (B3LYP) & $24724,23285,22323,19239$ & \\
$\mathrm{NiL}_{2} \mathrm{NH}_{3}$ (EDF1) & 21685,14794 & $\pi \rightarrow \pi^{*}, \mathrm{n} \rightarrow \pi^{*}, \mathrm{n} \rightarrow \pi^{*}$ \\
\hline $\mathrm{L}_{3}$ & $30769,22272,21186$ & $\pi \rightarrow \pi^{*},{ }^{1} \mathrm{~A}_{1 \mathrm{~g}} \rightarrow{ }^{1} \mathrm{E}_{1 \mathrm{~g}},{ }^{1} \mathrm{~A}_{1 \mathrm{~g}} \rightarrow{ }^{1} \mathrm{~B}_{1 \mathrm{~g}}$ \\
$\mathrm{NiL}_{3} \mathrm{NH}_{3}$ (Exp) & $31250,22472,21186$ & \\
$\mathrm{NiL}_{3} \mathrm{NH}_{3}$ (B3LYP) & $25454,23552,22339,19642$ & \\
$\mathrm{NiL}_{3} \mathrm{NH}_{3}$ (EDF1) & $22471,21209,15095$ & \\
\hline
\end{tabular}

Exp $=$ Experimental.

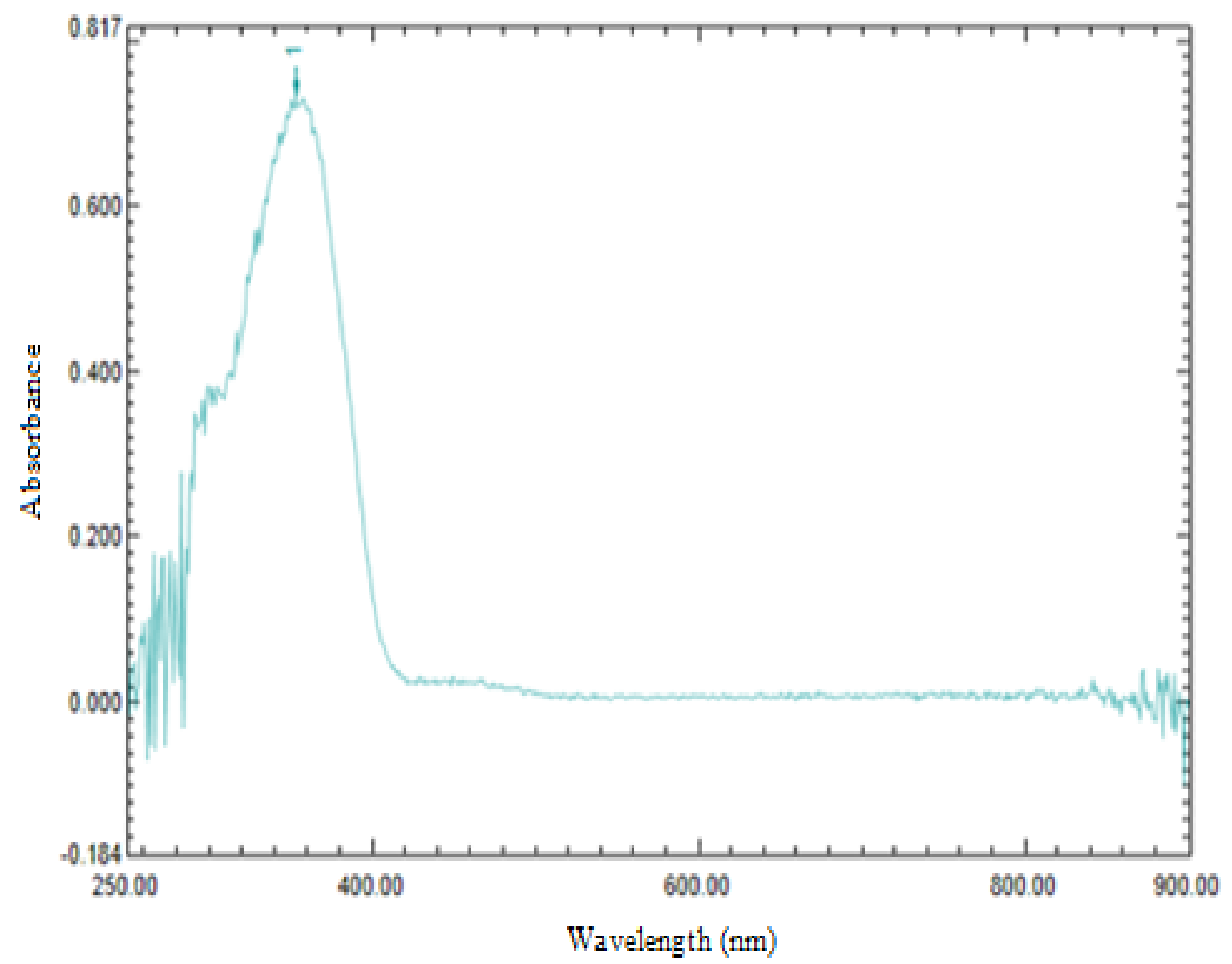

(A) 


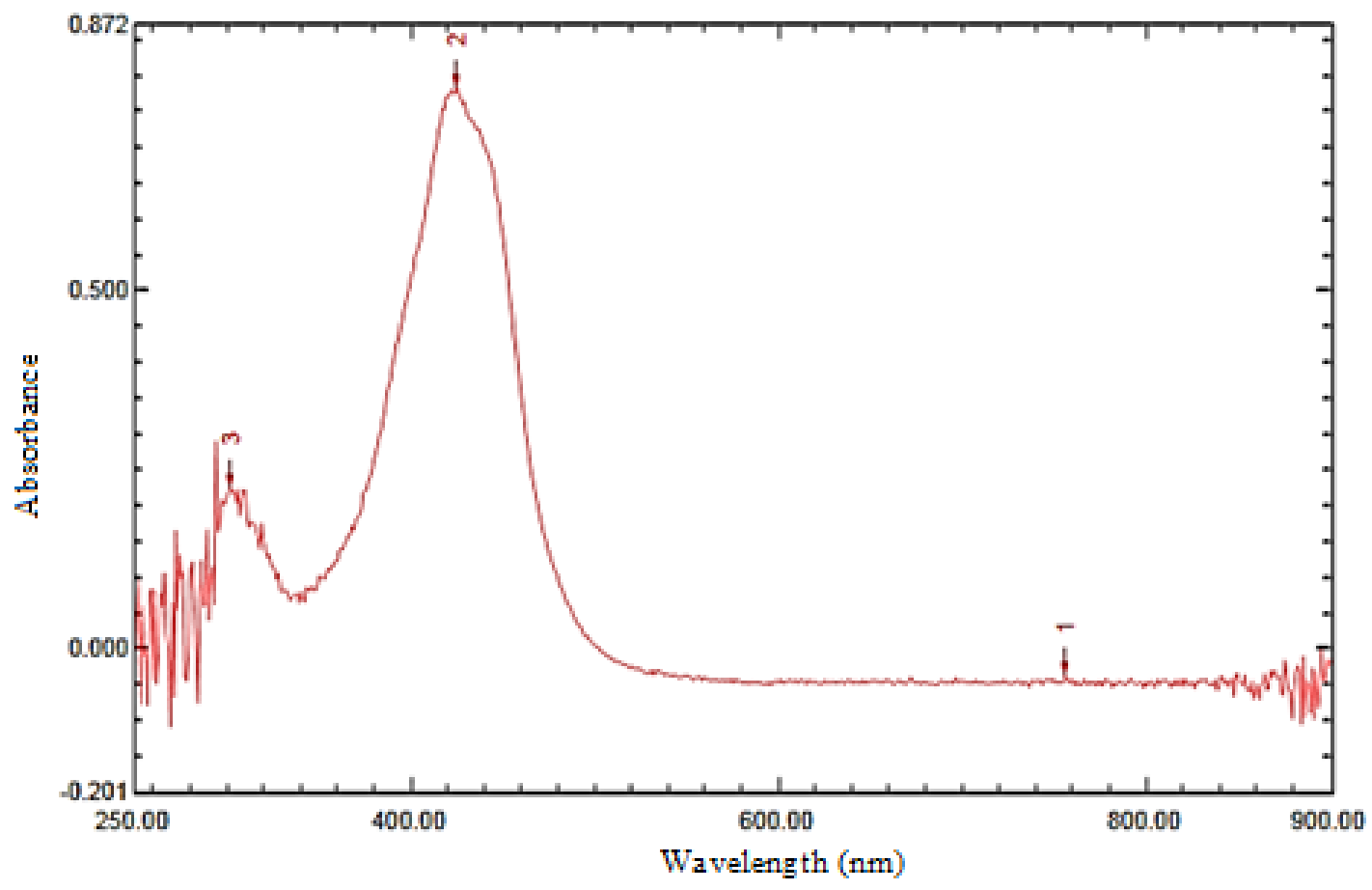

(B)

Figure 7. UV-Visible spectra of $\mathrm{L}_{1}(\mathrm{~A}), \mathrm{NiL}_{1} \mathrm{NH}_{3}$ (B).

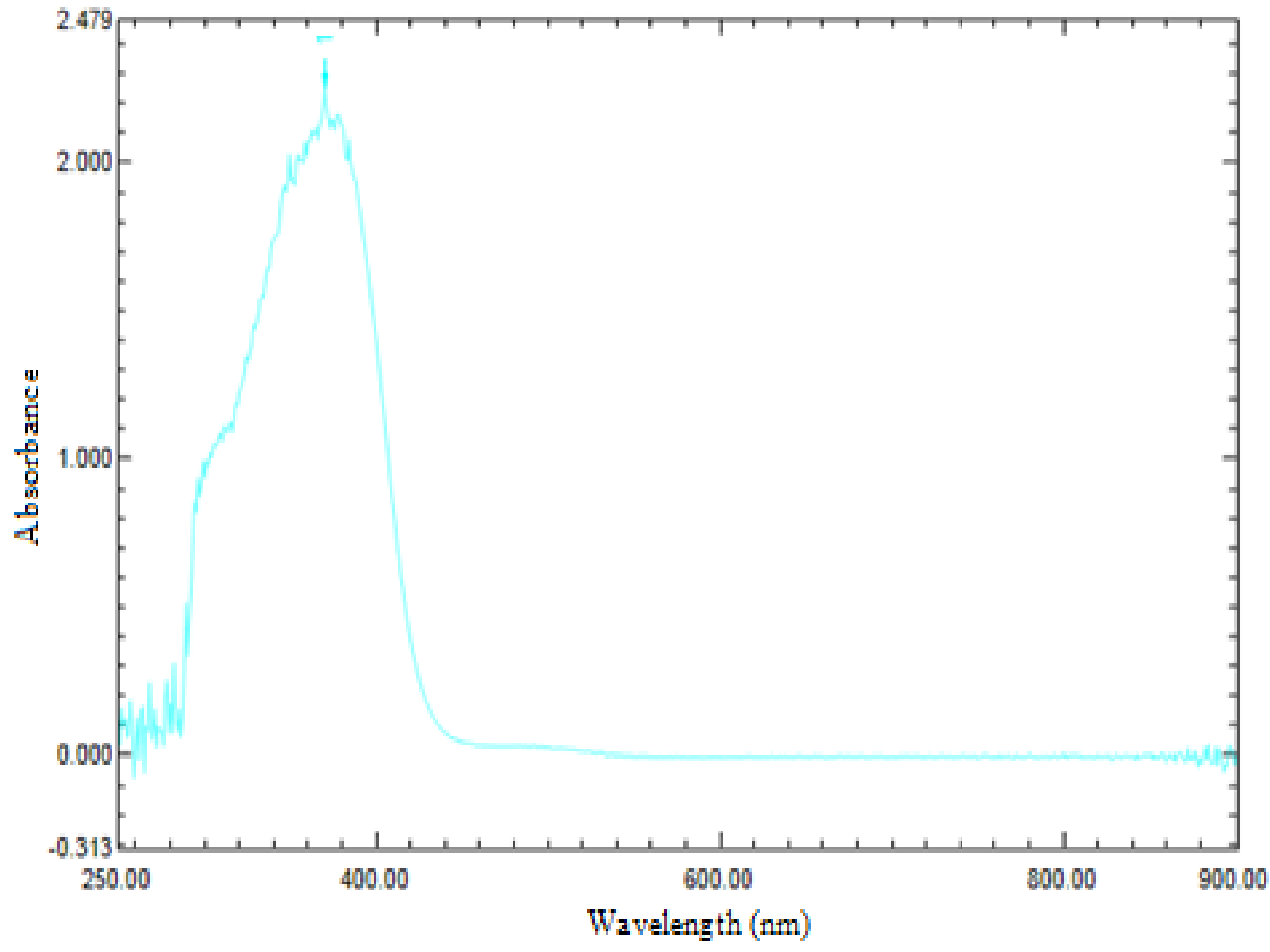

(A) 


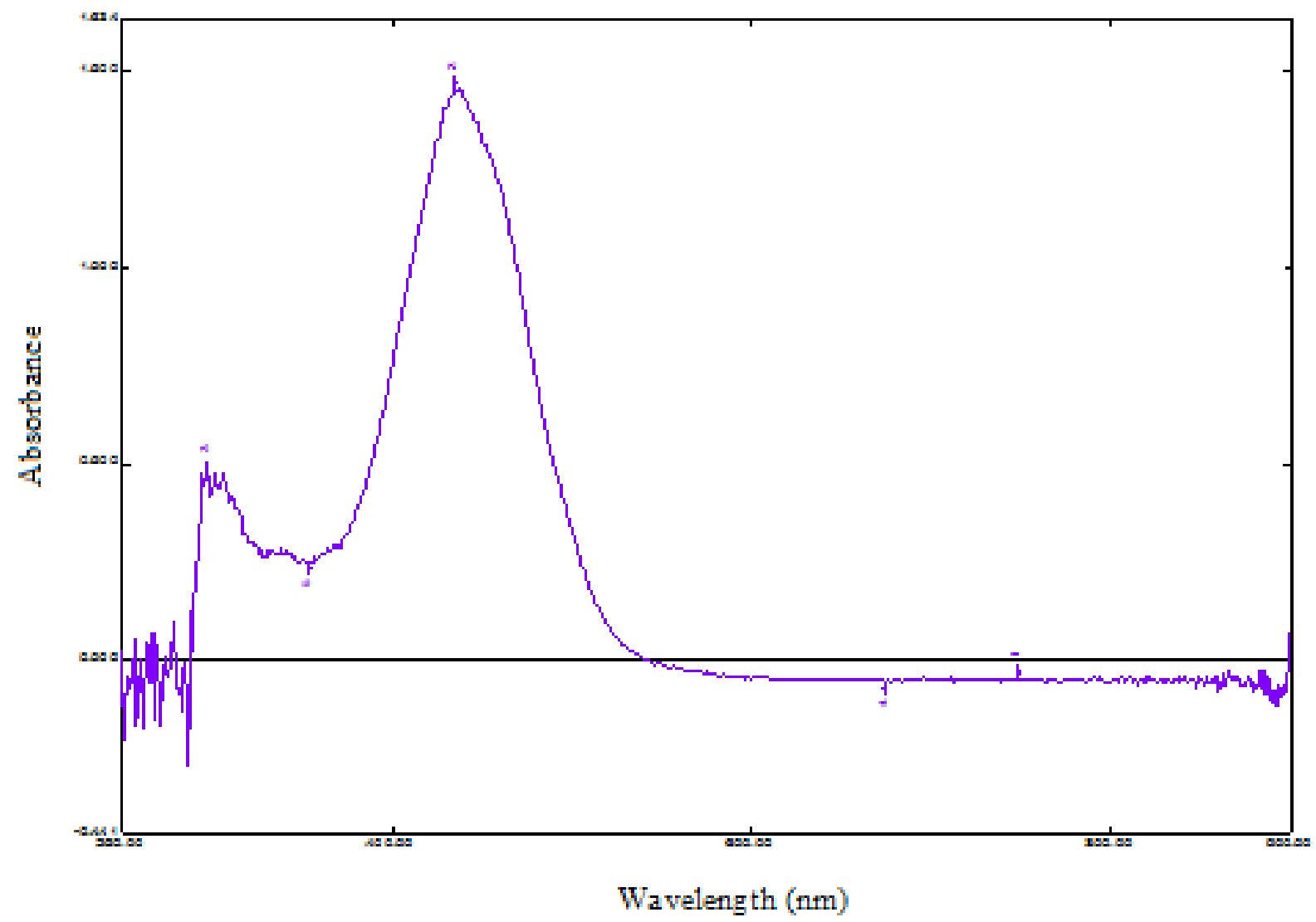

(B)

Figure 8. UV-Visible spectra of $\mathrm{L}_{2}(\mathrm{~A}), \mathrm{NiL}_{2} \mathrm{NH}_{3}(\mathrm{~B})$.

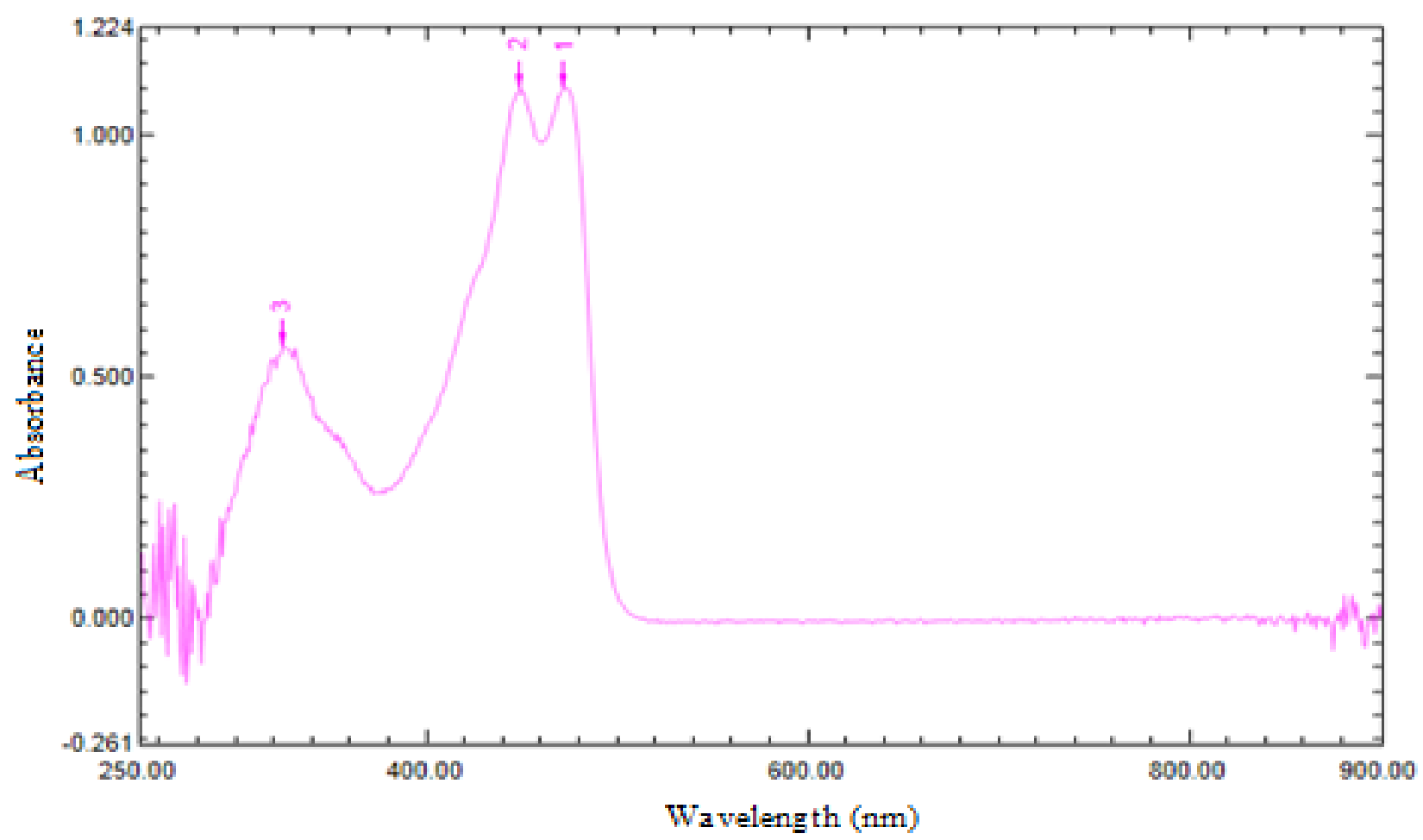

(A) 


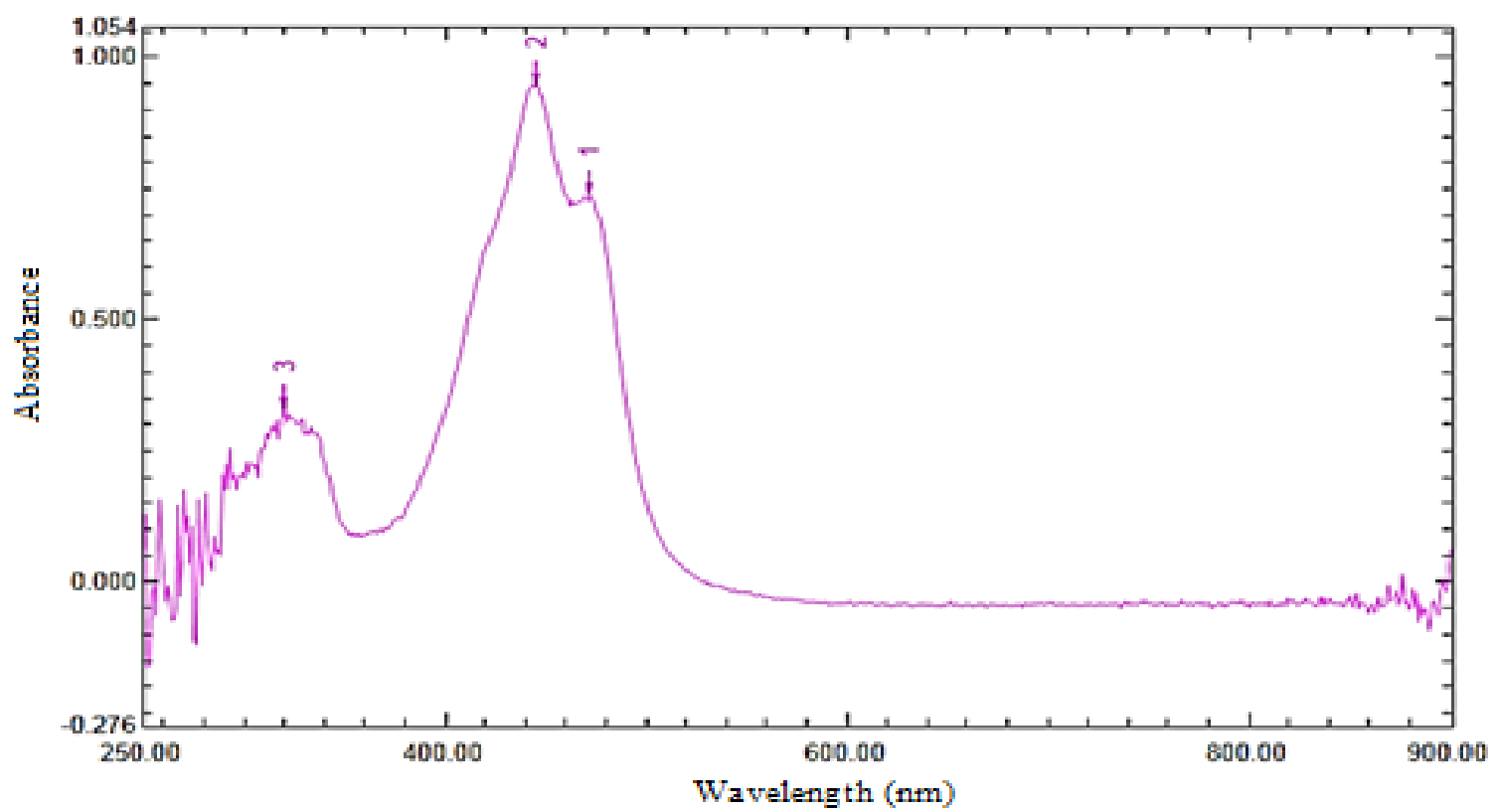

(B)

Figure 9. UV-Visible spectra of $\mathrm{L}_{3}(\mathrm{~A}), \mathrm{NiL}_{3} \mathrm{NH}_{3}$ (B)

\subsubsection{Theoretical IR spectra}

The theoretical IR vibrational frequency values of the Ni(II) complexes (Table 2) are in good agreement with the experimental values. The azomethine $(-\mathrm{HC}=\mathrm{N})$ absorption bands of the complexes appeared at $1654 \mathrm{~cm}^{-1}$ for both $\mathrm{NiL}_{1} \mathrm{NH}_{3}$ and $\mathrm{NiL}_{2} \mathrm{NH}_{3}$ while $\mathrm{NiL}_{3} \mathrm{NH}_{3}$ was at $1648 \mathrm{~cm}^{-1}$ at B3LYP/6-31G** level. Experimentally, these bands were observed at 1601 and $1600 \mathrm{~cm}^{-1}$ for the complexes. The phenolic $\mathrm{C}-\mathrm{O}$ stretching vibrations of the complexes appeared around 1340$1334 \mathrm{~cm}^{-1}$ in the theoretical data while the experimental values were observed around 1301$1261 \mathrm{~cm}^{-1}$. The experimental $\mathrm{v}(\mathrm{N}-\mathrm{H})$ stretching vibrations of $-\mathrm{NH}_{3}$ groups in the complexes appeared around $3336-3340 \mathrm{~cm}^{-1}$ while it was observed at $3592-3466 \mathrm{~cm}^{-1}$ in the theoretical spectra. The aromatic $\mathrm{v}(\mathrm{C}-\mathrm{H})$ stretching frequencies in the complexes were observed at $3218-3062 \mathrm{~cm}^{-1}$ in the theoretical data while the experimental were $3259-3010 \mathrm{~cm}^{-1}$. The characteristic $\mathrm{v}(\mathrm{C}=\mathrm{C})$ ring stretching vibrations of the complexes appeared at $1639-1400 \mathrm{~cm}^{-1}$ in the theoretical data, these bands appeared around $1584-1400 \mathrm{~cm}^{-1}$ in the experimental spectra. The $\mathrm{r}(\mathrm{Ni}-\mathrm{O})$ and $\mathrm{r}(\mathrm{Ni}-\mathrm{N})$ in the complexes were observed at 531-465 and $579-531 \mathrm{~cm}^{-1}$ in the theoretical spectra. These bands were observed at 485-471 and 550-508 $\mathrm{cm}^{-1}$ in the experimentally.

Table 2. Some selected theoretical IR data of the complexes.

\begin{tabular}{|c|c|c|c|}
\hline IR bands $/ \mathrm{cm}^{-1}$ & $\mathrm{NiL}_{1} \mathbf{N H}_{3}$ & $\mathrm{NiL}_{2} \mathrm{NH}_{3}$ & $\mathrm{NiL}_{3} \mathrm{NH}_{3}$ \\
\hline $\begin{array}{l}\mathrm{v}(\mathrm{N}-\mathrm{H})(\mathrm{B} 3 \mathrm{LYP}) \\
(\mathrm{EDF} 1)\end{array}$ & $\begin{array}{l}3592- \\
3463 \\
3539- \\
3408\end{array}$ & $\begin{array}{l}3596- \\
3467 \\
3536- \\
3403\end{array}$ & $\begin{array}{l}3597- \\
3466 \\
3542- \\
3407\end{array}$ \\
\hline $\begin{array}{l}\mathrm{r}(\mathrm{C}-\mathrm{H})(\mathrm{B} 3 \mathrm{LYP}) \\
(\mathrm{EDF} 1)\end{array}$ & $\begin{array}{l}3212- \\
3174 \\
3171- \\
3122\end{array}$ & $\begin{array}{l}3200- \\
3062 \\
3182- \\
3024\end{array}$ & $\begin{array}{l}3218- \\
3174 \\
3176- \\
3135\end{array}$ \\
\hline $\begin{array}{l}\mathrm{v}(\mathrm{C}=\mathrm{N})(\mathrm{B} 3 \mathrm{LYP}) \\
(\mathrm{EDF} 1)\end{array}$ & $\begin{array}{l}1654 \\
1608\end{array}$ & $\begin{array}{l}1654 \\
1591\end{array}$ & $\begin{array}{l}1648 \\
1615\end{array}$ \\
\hline $\begin{array}{l}\mathrm{r}(\mathrm{N}-\mathrm{H}) \text { bending } \\
(\mathrm{B} 3 \mathrm{LYP}) \\
(\mathrm{EDF} 1)\end{array}$ & $\begin{array}{l}1662- \\
1665 \\
1640- \\
1622\end{array}$ & $\begin{array}{l}1680- \\
1658 \\
1636- \\
1633\end{array}$ & $\begin{array}{l}1670- \\
1657 \\
1639- \\
1417\end{array}$ \\
\hline $\begin{array}{l}\mathrm{v}(\mathrm{C}=\mathrm{C})(\mathrm{B} 3 \mathrm{LYP}) \\
(\mathrm{EDF} 1)\end{array}$ & $\begin{array}{l}1639- \\
1404 \\
1593- \\
1452\end{array}$ & $\begin{array}{l}1639- \\
1413 \\
1608- \\
1429\end{array}$ & $\begin{array}{l}1633- \\
1400 \\
1606- \\
1417\end{array}$ \\
\hline $\begin{array}{l}\mathrm{v}(\mathrm{C}-\mathrm{O})(\mathrm{B} 3 \mathrm{LYP}) \\
(\mathrm{EDF} 1)\end{array}$ & $\begin{array}{l}1340 \\
1313\end{array}$ & $\begin{array}{l}1339 \\
1312\end{array}$ & $\begin{array}{l}1334 \\
1308\end{array}$ \\
\hline $\begin{array}{l}\mathrm{v}(\mathrm{C}-\mathrm{H}) \text { bending } \\
(\mathrm{B} 3 \mathrm{LYP}) \\
(\mathrm{EDF} 1)\end{array}$ & $\begin{array}{l}891-666 \\
889-666\end{array}$ & $\begin{array}{l}871-663 \\
894-669\end{array}$ & $\begin{array}{l}886-666 \\
895-650\end{array}$ \\
\hline $\begin{array}{l}\mathrm{v}(\mathrm{Ni}-\mathrm{O})(\mathrm{B} 3 \mathrm{LYP}) \\
(\mathrm{EDF} 1)\end{array}$ & $\begin{array}{l}500 \\
499\end{array}$ & $\begin{array}{l}465 \\
458\end{array}$ & $\begin{array}{l}531 \\
525\end{array}$ \\
\hline $\begin{array}{l}\mathrm{v}(\mathrm{Ni}-\mathrm{N})(\mathrm{B} 3 \mathrm{LYP}) \\
(\mathrm{EDF} 1)\end{array}$ & $\begin{array}{l}538 \\
532\end{array}$ & $\begin{array}{l}531 \\
525\end{array}$ & $\begin{array}{l}579 \\
566\end{array}$ \\
\hline
\end{tabular}




\subsubsection{Theoretical NMR spectra}

The theoretical chemical shift values of the $\mathrm{Ni}$ (II) mixed-ligand complexes (Table 3) are in good agreement with the experimental values. The data obtained at B3LYP/6-31G** level showed the aromatic hydrogen in $\mathrm{NiL}_{1} \mathrm{NH}_{3}$ : H17, H15, H14, $\mathrm{H} 2, \mathrm{H} 11, \mathrm{H} 10, \mathrm{H} 6, \mathrm{H} 13$ at 8.65, 7.94, 7.84, 7.66, $8.12,7.57,8.26,7.53 \mathrm{ppm}$ respectively. These were experimentally observed around 7.75-6.46 ppm. The azomethine $(-\mathrm{HC}=\mathrm{N})$ hydrogen and the three hydrogen in the $-\mathrm{NH}_{3}$ group were observed at 10.07 and $2.60 \mathrm{ppm}$ respectively in the theoretical spectra while they appeared at 8.79 and $2.37 \mathrm{ppm}$ respectively in the experimental spectra. The aromatic carbon in the complex appeared in the range 157.40-108.56 ppm, these were observed experimentally in the range $162.96-114.75 \mathrm{ppm}$. The azomethine carbon signal appeared at $158.82 \mathrm{ppm}$ in the theoretical calculations while it was experimentally observed at $167.43 \mathrm{ppm}$. Moreover, the aromatic hydrogen in $\mathrm{NiL}_{2} \mathrm{NH}_{3}$ : H10, H13, H15, H17, H17, H14, H11, H6 were observed at 7.54, 7.51, 7.94, 8.64, 7.77, 7.62, 7.79 $\mathrm{ppm}$ in the theoretical spectra, these appeared in the range 7.71-6.45 $\mathrm{ppm}$ in the experimental study. The azomethine $(-\mathrm{HC}=\mathrm{N})$ hydrogen and the three hydrogen in the $-\mathrm{NH}_{3}$ group appeared at 10.04 and $2.52 \mathrm{ppm}$ respectively in the theoretical calculations while they were experimentally observed at 8.79 and $2.37 \mathrm{ppm}$ respectively.

Table 3. Theoretical electronic spectra data of the complexes.

\begin{tabular}{|c|c|c|c|c|c|c|}
\hline \multirow{2}{*}{$\begin{array}{l}\text { Positions } \\
\text { of H \& C }\end{array}$} & \multicolumn{2}{|c|}{$\mathrm{NiL}_{1} \mathrm{NH}_{3} \delta / \mathrm{ppm}$} & \multicolumn{2}{|c|}{$\mathrm{NiL}_{2} \mathrm{NH}_{3} \delta / \mathrm{ppm}$} & \multicolumn{2}{|c|}{$\mathrm{NiL}_{3} \mathrm{NH}_{3} \delta / p p m$} \\
\hline & B3LYP & EDF1 & B3LYP & EDF1 & B3LYP & EDF1 \\
\hline $\begin{array}{l}\mathrm{H} 1 \\
\mathrm{C} 1\end{array}$ & $\begin{array}{c}2.60 \\
110.41\end{array}$ & $\begin{array}{c}- \\
110.00\end{array}$ & $\begin{array}{c}2.52 \\
142.89\end{array}$ & $\begin{array}{c}3.07 \\
142.19\end{array}$ & $\begin{array}{c}8.33 \\
159.97\end{array}$ & $\begin{array}{c}8.45 \\
154.38\end{array}$ \\
\hline $\begin{array}{l}\mathrm{H} 2 \\
\mathrm{C} 2\end{array}$ & $\begin{array}{c}7.66 \\
128.54\end{array}$ & $\begin{array}{c}7.84 \\
124.18\end{array}$ & $\begin{array}{c}4.63 \\
114.54\end{array}$ & $\begin{array}{c}4.84 \\
110.42\end{array}$ & $\begin{array}{c}8.58 \\
122.05\end{array}$ & $\begin{array}{c}8.65 \\
119.41\end{array}$ \\
\hline $\begin{array}{l}\mathrm{H} 3 \\
\mathrm{C} 3\end{array}$ & $\begin{array}{c}2.60 \\
118.64\end{array}$ & $\begin{array}{c}- \\
118.12\end{array}$ & $\begin{array}{c}2.52 \\
118.90\end{array}$ & $\begin{array}{c}3.07 \\
118.54\end{array}$ & $\begin{array}{c}9.26 \\
114.40\end{array}$ & $\begin{array}{c}9.37 \\
113.33\end{array}$ \\
\hline $\begin{array}{l}\mathrm{H} 4 \\
\mathrm{C} 4\end{array}$ & $\begin{array}{c}10.07 \\
157.28\end{array}$ & $\begin{array}{c}9.86 \\
151.07\end{array}$ & $\begin{array}{c}10.04 \\
153.62\end{array}$ & $\begin{array}{c}9.86 \\
146.22\end{array}$ & $\begin{array}{c}2.59 \\
130.06\end{array}$ & $\begin{array}{c}3.09 \\
126.45\end{array}$ \\
\hline $\begin{array}{l}\mathrm{H} 5 \\
\mathrm{C} 5\end{array}$ & $\begin{array}{c}2.60 \\
118.28\end{array}$ & $\begin{array}{c}- \\
115.09\end{array}$ & $\begin{array}{c}2.52 \\
118.31\end{array}$ & $\begin{array}{c}3.07 \\
114.74\end{array}$ & $\begin{array}{c}8.80 \\
122.42\end{array}$ & $\begin{array}{c}8.91 \\
120.96\end{array}$ \\
\hline $\begin{array}{l}\text { H6 } \\
\text { C6 }\end{array}$ & $\begin{array}{c}8.26 \\
125.78\end{array}$ & $\begin{array}{c}8.38 \\
121.47\end{array}$ & $\begin{array}{c}7.79 \\
110.01\end{array}$ & $\begin{array}{c}7.91 \\
106.15\end{array}$ & $\begin{array}{c}8.50 \\
124.73\end{array}$ & $\begin{array}{c}8.68 \\
122.36\end{array}$ \\
\hline $\begin{array}{l}\mathrm{H} 7 \\
\mathrm{C} 7\end{array}$ & $\begin{array}{c}- \\
158.82\end{array}$ & $\begin{array}{c}- \\
154.81\end{array}$ & $\begin{array}{c}4.63 \\
158.06\end{array}$ & $\begin{array}{c}4.84 \\
154.83\end{array}$ & $\begin{array}{c}11.19 \\
111.41\end{array}$ & $\begin{array}{c}10.97 \\
112.29\end{array}$ \\
\hline $\begin{array}{l}\mathrm{H} 8 \\
\mathrm{C} 8\end{array}$ & $\begin{array}{c}- \\
135.68\end{array}$ & $\begin{array}{c}- \\
135.74\end{array}$ & $\begin{array}{c}4.63 \\
136.22\end{array}$ & $\begin{array}{c}4.84 \\
135.30\end{array}$ & $\begin{array}{c}- \\
157.97\end{array}$ & $\begin{array}{c}- \\
151.16\end{array}$ \\
\hline $\begin{array}{l}\mathrm{H} 9 \\
\mathrm{C} 9\end{array}$ & $\begin{array}{c}- \\
157.40\end{array}$ & $\begin{array}{c}- \\
151.11\end{array}$ & $\begin{array}{c}- \\
153.79\end{array}$ & $\begin{array}{c}- \\
152.81\end{array}$ & $\begin{array}{c}7.96 \\
120.44\end{array}$ & $\begin{array}{c}8.14 \\
117.30\end{array}$ \\
\hline $\begin{array}{l}\mathrm{H} 10 \\
\mathrm{C} 10\end{array}$ & $\begin{array}{c}7.57 \\
114.37\end{array}$ & $\begin{array}{c}7.83 \\
111.90\end{array}$ & $\begin{array}{c}7.54 \\
114.13\end{array}$ & $\begin{array}{c}7.84 \\
111.99\end{array}$ & $\begin{array}{c}8.40 \\
127.66\end{array}$ & $\begin{array}{c}8.45 \\
123.08\end{array}$ \\
\hline $\begin{array}{l}\text { H11 } \\
\text { C11 }\end{array}$ & $\begin{array}{c}8.12 \\
123.14\end{array}$ & $\begin{array}{c}8.20 \\
119.75\end{array}$ & $\begin{array}{c}7.62 \\
123.07\end{array}$ & $\begin{array}{c}7.70 \\
119.78\end{array}$ & $\begin{array}{c}761 \\
138.83\end{array}$ & $\begin{array}{c}7.88 \\
127.20\end{array}$ \\
\hline $\begin{array}{l}\mathrm{H} 12 \\
\mathrm{C} 12\end{array}$ & $\begin{array}{c}- \\
108.56\end{array}$ & $\begin{array}{c}- \\
107.84\end{array}$ & $\begin{array}{c}- \\
108.64\end{array}$ & $\begin{array}{c}- \\
107.86\end{array}$ & $\begin{array}{c}7.60 \\
136.45\end{array}$ & $\begin{array}{c}8.14 \\
132.60\end{array}$ \\
\hline $\begin{array}{l}\mathrm{H} 13 \\
\mathrm{C} 13\end{array}$ & $\begin{array}{c}7.53 \\
107.72\end{array}$ & $\begin{array}{c}7.71 \\
107.49\end{array}$ & $\begin{array}{c}7.51 \\
108.84\end{array}$ & $\begin{array}{c}7.72 \\
107.59\end{array}$ & $\begin{array}{c}7.97 \\
122.57\end{array}$ & $\begin{array}{c}8.14 \\
119.63\end{array}$ \\
\hline $\begin{array}{l}\mathrm{H} 14 \\
\mathrm{C} 14\end{array}$ & $\begin{array}{c}7.84 \\
-\end{array}$ & $\begin{array}{c}8.03 \\
-\end{array}$ & $\begin{array}{c}7.77 \\
52.28\end{array}$ & $\begin{array}{c}7.95 \\
54.69\end{array}$ & $\begin{array}{c}2.59 \\
108.43\end{array}$ & $\begin{array}{c}3.09 \\
107.31\end{array}$ \\
\hline $\begin{array}{l}\mathrm{H} 15 \\
\mathrm{C} 15\end{array}$ & $\begin{array}{c}7.94 \\
-\end{array}$ & $\begin{array}{c}8.09 \\
-\end{array}$ & $\begin{array}{c}7.94 \\
-\end{array}$ & $\begin{array}{c}8.09 \\
-\end{array}$ & $\begin{array}{c}- \\
155.97\end{array}$ & $\begin{array}{c}- \\
152.23\end{array}$ \\
\hline $\begin{array}{l}\text { H16 } \\
\text { C16 }\end{array}$ & - & $\begin{array}{l}- \\
-\end{array}$ & - & - & $\begin{array}{c}- \\
114.05\end{array}$ & $\begin{array}{c}- \\
111.92\end{array}$ \\
\hline $\begin{array}{l}\mathrm{H} 17 \\
\mathrm{C} 17\end{array}$ & $\begin{array}{c}8.65 \\
-\end{array}$ & $\begin{array}{c}8.72 \\
-\end{array}$ & $\begin{array}{c}8.64 \\
-\end{array}$ & $\begin{array}{c}7.70 \\
-\end{array}$ & $\begin{array}{c}- \\
108.83\end{array}$ & 112.29 \\
\hline $\begin{array}{l}\text { H18 } \\
\text { C18 }\end{array}$ & - & - & - & - & $\begin{array}{c}2.59 \\
-\end{array}$ & $\begin{array}{c}3.09 \\
-\end{array}$ \\
\hline
\end{tabular}


The chemical shift of the three hydrogen in the $-\mathrm{OCH}_{3}$ group appeared at $4.63 \mathrm{ppm}$ in the theoretical calculations and at $3.69 \mathrm{ppm}$ in the experimental spectra. The aromatic carbon in the complex appeared in the range 153.79-108.64 ppm in the theoretical spectra, these were observed experimentally in the range $156.48-114.77 \mathrm{ppm}$. The carbon in the azomethine and $-\mathrm{OCH}_{3}$ groups appeared at 158.06 and $52.28 \mathrm{ppm}$ respectively in the theoretical calculations, these were experimentally observed at 167.38 and 55.96 ppm respectively.

However, in $\mathrm{NiL}_{3} \mathrm{NH}_{3}$, the hydrogen in the ring: $\mathrm{H} 2$, H9, H10, H6, H1, H3, H5, H11, H13, H12 were observed at 8.58, 7.96, 8.40, 8.50, 8.33, 9.26, 8.80, $7.61,7.97,7.60 \mathrm{ppm}$ in the theoretical calculations. These were experimentally reported in the range 8.49-6.30 ppm. The azomethine $(-\mathrm{HC}=\mathrm{N})$ and $-\mathrm{NH}_{3}$ group hydrogen were observed at 11.19 and $2.59 \mathrm{ppm}$ respectively in the theoretical spectra while they were reported in the experimental study at 9.25 and $2.37 \mathrm{ppm}$ respectively. The aromatic carbon in the complex appeared in the range 157.40-108.56 ppm in the theoretical data, these appeared experimentally in the range 162.96$114.75 \mathrm{ppm}$. The azomethine carbon was observed at $159.97 \mathrm{ppm}$ in the theoretical data and at 167.17 ppm in the experimental spectra.

\subsubsection{Theoretical UV-Vis spectra}

Table 1 compared the experimental and theoretical electronic spectra of the complexes. The theoretical electronic spectra data agree with the experimental values. The agreement between the theoretical and experimental electronic spectra data corroborated the suggested structures. The theoretical spectra of $\mathrm{NiL}_{1} \mathrm{NH}_{3}$ as calculated at B3LYP/6-31G level showed three absorption bands at 23817, 224222, $19377 \mathrm{~cm}^{-1}$. These bands were obtained when electrons were promoted from HOMO $\rightarrow$ LUMO, HOMO-6 $\rightarrow$ LUMO and HOMO-2 $\rightarrow$ LUMO+1 respectively. $\mathrm{NiL}_{2} \mathrm{NH}_{3}$ showed four absorption bands at 24724, 23285, $22323,19239 \mathrm{~cm}^{-1}$, these bands were related to the promotion of electrons from HOMO $\rightarrow$ LUMO, HOMO- $1 \rightarrow$ LUMO, HOMO-6 $\rightarrow$ LUMO +1 , HOMO-2 $\rightarrow$ LUMO+1 respectively. Similarly, $\mathrm{NiL}_{3} \mathrm{NH}_{3}$ displayed four absorption bands at 25454, 23552, 22339, $19642 \mathrm{~cm}^{-1}$. These bands were obtained when electrons were promoted from HOMO- $\rightarrow$ LUMO, HOMO $\rightarrow$ LUMO, HOMO-
$7 \rightarrow$ LUMO+1 and HOMO-2 $\rightarrow$ LUMO+1 respectively.

\subsection{Geometry of the $\mathrm{Ni}(\mathrm{II})$ mixed-ligand complexes}

In the absence of available X-ray crystallographic data, the use of quantum chemical methods in determining the equilibrium geometries of the mixed-ligand complexes becomes an important tool. The B3LYP/6-31G** and EDF1/6$31 \mathrm{G}^{* *}$ methods were used to predict the geometries of the $\mathrm{Ni}(\mathrm{II})$ mixed-ligand complexes. The experimental and theoretical observations earlier discussed have confirmed the formation of the mixed-ligand complexes. Hence, the proposed and optimized structures of the mixed-ligand complexes are shown in Fig. 10. The geometry of the mixed-ligand complexes predicted by both methods of calculation was a distorted square planar. The angles N1-Ni1-N2, O1-Ni1-O2, $\mathrm{N} 1-\mathrm{Ni1}-\mathrm{O} 2, \quad \mathrm{~N} 1-\mathrm{Ni} 1-\mathrm{O} 1, \quad \mathrm{~N} 2-\mathrm{Ni1}-\mathrm{O} 2$, N2-Ni1-O1 (Table S1, supplementary data) indicated that the coordination geometry of the nickel atom is distorted from a square planar. The bond distances Ni1-N1, Ni1-N2, Ni1-O1, Ni1-O2 (Table S1, supplementary data) were in the ranges observed for the analogous compounds of nickel square planar complexes containing the tridentate Schiff bases and N-donor coligands ${ }^{11,28,29}$.

In $\mathrm{NiL}_{1} \mathrm{NH}_{3}$, the HOMO which represents $\pi$ electrons of the system spread over the Ni(II) ion and $\mathrm{N}$-(salicylidene)-o-aminophenol ligand with most of the electron density concentrated on the $o$ aminophenol subunit while the LUMO have most of the electron density concentrated on the salicylidene subunit. Similarly in $\mathrm{NiL}_{2} \mathrm{NH}_{3}$, the HOMO spread over the $\mathrm{Ni}$ (II) ion and $\mathrm{N}$-(5methoxysalicylidene)-o-aminophenol ligand with most of the electron density concentrated on the 5methoxysalicylidene subunit while the LUMO have most of the electron density concentrated on the salicylidene subunit excluding the methoxy group. In $\mathrm{NiL}_{3} \mathrm{NH}_{3}$, the HOMO spread over the $\mathrm{Ni}$ (II) ion and $\mathrm{N}$-(naphthalidene)-o-aminophenol with most of the electron density concentrated on the azomethine group and $o$-aminophenol subunit while the LUMO have most of the electron density concentrated on one of the benzene ring of the naphthalidene and the azomethine group. 
(HOMO)<smiles>NN1Oc2ccccc2OC1N1Cc2ccccc2O1</smiles><smiles>COc1ccc2c(c1)C=NC(N)(N)Oc1ccccc1O2</smiles><smiles>NN1N=Cc2c(ccc3ccccc23)Oc2ccccc2O1</smiles>
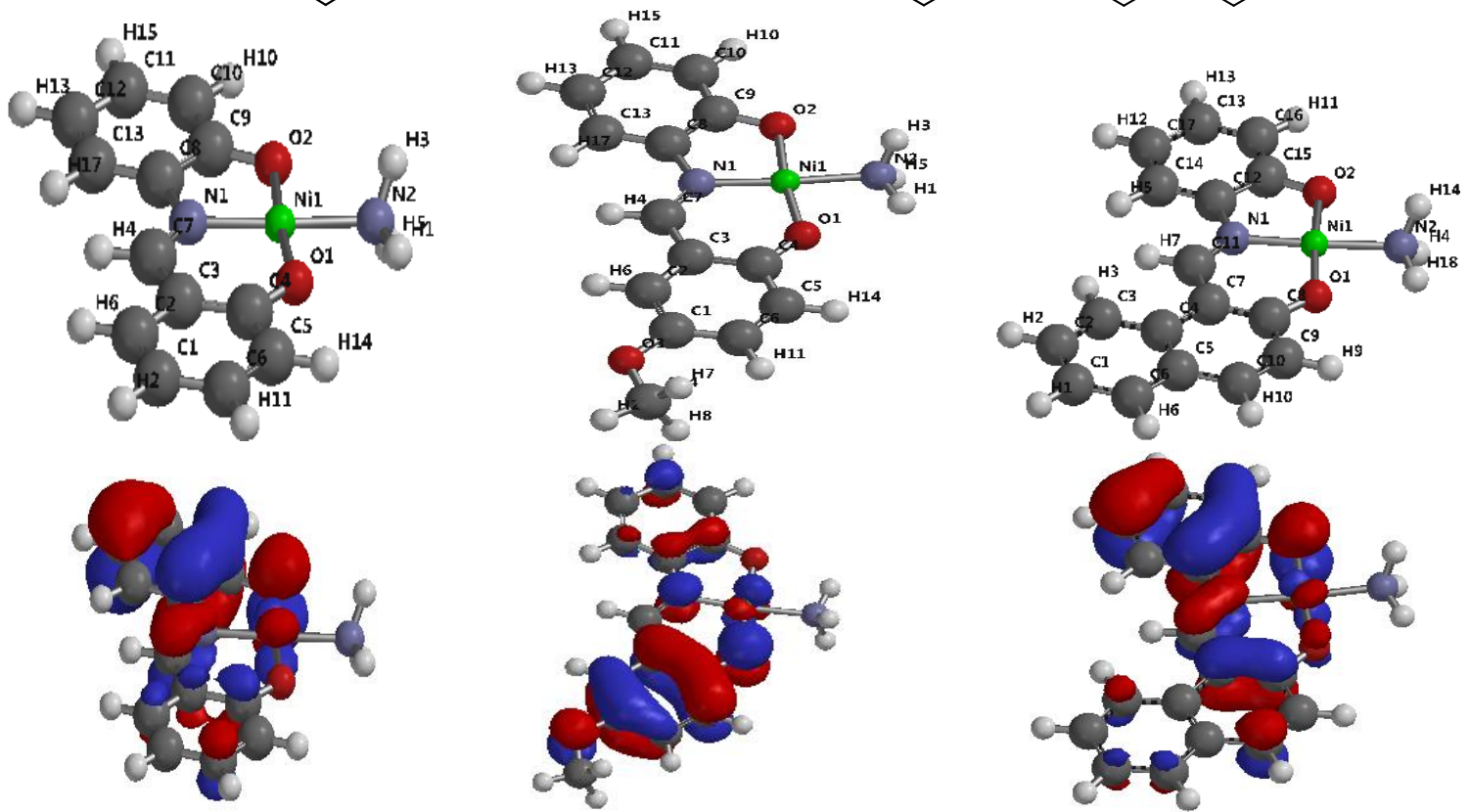

(LUMO)

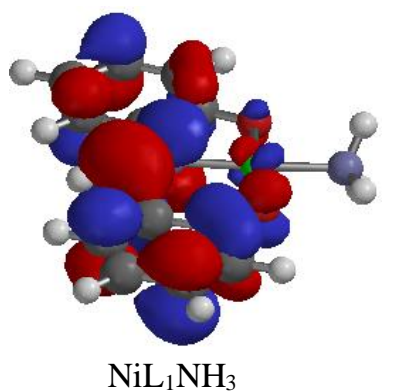

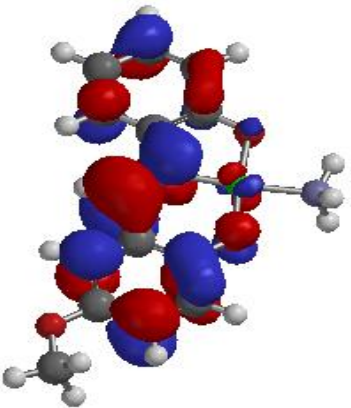

$\mathrm{NiL}_{2} \mathrm{NH}_{3}$

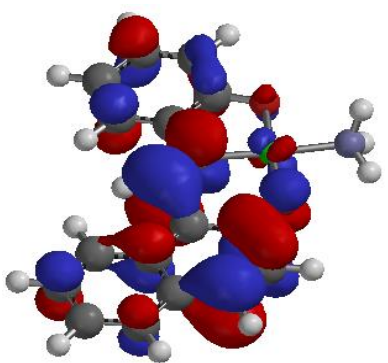

$\mathrm{NiL}_{3} \mathrm{NH}_{3}$

Figure. 10. Proposed and optimized structures of the complexes at B3LYP/6-31G** level.

\subsection{Antibacterial activity}

The results of the antibacterial activities of the Schiff bases and the mixed-ligand complexes are summarized in Table 4. The antibacterial results revealed that all the synthesized Schiff base ligands and the mixed-ligand complexes exhibited antibacterial activities. The mixed-ligand complexes exhibited better inhibitory effects compared to the parent Schiff bases. The enhancement in the antibacterial activities of the complexes can be explained based on chelation theory and probably the presence of ammonia molecules in the complexes. Chelation makes the ligands more powerful and potent bactericidal agents; consequently, killing more bacteria than the free ligands. It facilitates the ability of the complexes to cross the cell membrane. On chelation, the polarity of the metal ion reduces to a greater extent due to the overlap of the ligand orbital and partial sharing of the positive charge of the metal ion with donor groups. This process thus 
increases the lipophilic nature of the compound which in turn favors penetration through the cell wall of the bacteria. These complexes also disturb the respiration process of the cell and thus block the synthesis of proteins, which restricts further growth of the organisms ${ }^{12,29,31}$.

In comparison with standard Gentamycin, $\mathrm{NiL}_{2} \mathrm{NH}_{3}$ exhibited more inhibitory effects against the bacterial strains than standard Gentamycin. Moreover, all the complexes showed more potent activities against $S$. agalactiae than standard Gentamycin which was inactive against it. The methoxy-substituted $\mathrm{Ni}$ (II) complex $\left(\mathrm{NiL}_{2} \mathrm{NH}_{3}\right)$ exhibited the most potent activity among the mixed-ligand complexes.

Table 4. Antibacterial activities of the Schiff bases and the mixed-ligand complexes.

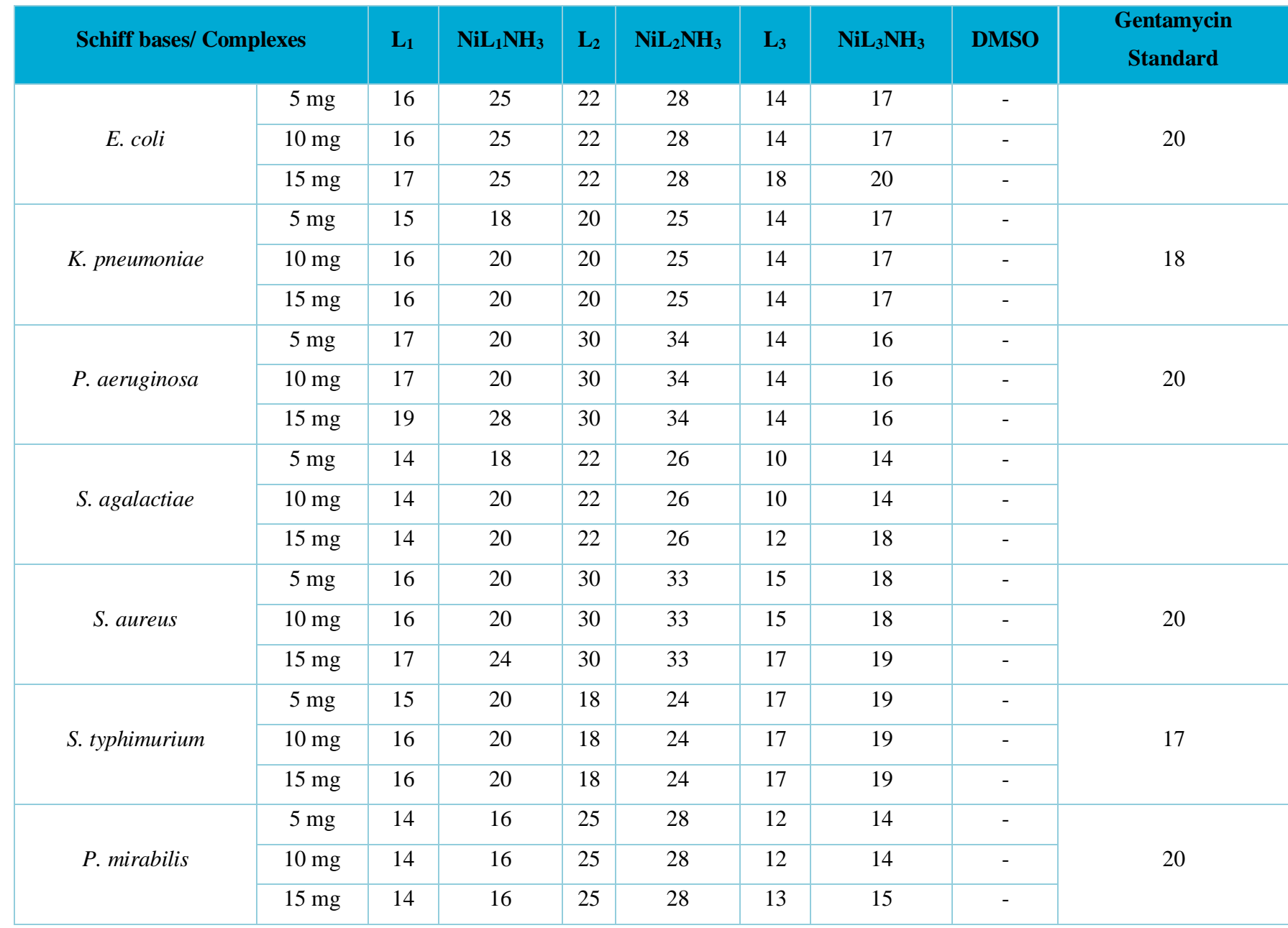

Resistant, not sensitive $(<8 \mathrm{~mm})$, sensitive $(9-14 \mathrm{~mm})$, very sensitive $(15-19 \mathrm{~mm})$ and ultrasensitive $(>20 \mathrm{~mm})^{16}$.

\subsection{Total antioxidant capacity}

The results of the total antioxidant capacities of the Schiff bases and the NI(II) mixed-ligand complexes are presented in Table 5. The mixedligand complexes showed higher total antioxidant capacities than the Schiff base ligands. $\mathrm{NiL}_{2} \mathrm{NH}_{3}$ exhibited the highest TAC among the mixed-ligand complexes. The difference in the TAC of the Schiff bases and the mixed-ligand complexes could be due to the coordination of the metal ions and probably the presence of ammonia molecules in the complexes. The coordination of metal after complexation of the system increases its capacity to stabilize unpaired electrons and consequently, to scavenge free radicals ${ }^{27}$. Hence, the mixed-ligand complexes are better antioxidants than the free Schiff base ligands. 
Table 5. Total antioxidant capacities of the Schiff bases and the mixed-ligand complexes.

\begin{tabular}{|l|l|}
\hline Schiff bases/Complexes & TAC $\boldsymbol{\mu g}$ per mg AA \\
\hline $\mathrm{L}_{1}$ & 0.68 \\
\hline $\mathrm{NiL}_{1} \mathrm{NH}_{3}$ & 0.96 \\
\hline $\mathrm{L}_{2}$ & 0.78 \\
\hline $\mathrm{NiL}_{2} \mathrm{NH}_{3}$ & 1.27 \\
\hline $\mathrm{L}_{3}$ & 0.62 \\
\hline $\mathrm{NiL}_{3} \mathrm{NH}_{3}$ & 0.71 \\
\hline
\end{tabular}

\section{Conclusions}

Nickel(II) mixed-ligand complexes containing ammonia, N-(salicylidene)-o-aminophenol, $\mathrm{N}-(5-$ methoxysalicylidene)-o-aminophenol and $\mathrm{N}-(2-$ hydroxy-1-naphthalidene)-o-aminophenol were synthesized and characterized by different techniques. The melting points, elemental analyses, IR, ${ }^{1} \mathrm{H}$ NMR, ${ }^{13} \mathrm{C}$ NMR and UV-Visible confirmed the formation of the mixed-ligand complexes. Theoretical calculations of the structures of the $\mathrm{Ni}$ (II) mixed-ligand complexes, their UV-Visible and IR and NMR spectra were performed to augment the experimental results. Based on the electronic spectra data, elemental analyses and the theoretical calculations, a distorted square planar geometry was proposed for the complexes. The antibacterial and total antioxidant activities of the complexes follow the order: $\mathrm{NiL}_{2} \mathrm{NH}_{3}>\mathrm{NiL}_{1} \mathrm{NH}_{3}$ $>\mathrm{NiL}_{3} \mathrm{NH}_{3}$.

\section{Acknowledgments}

Abidemi Iyewumi Demehin appreciates the Organization of Women in Science in Developing World (OWSD), Trieste, Italy, for the research fellowship granted to her to study in the Department of Chemistry, University of Malaya, Kuala Lumpur, Malaysia. She is grateful to Prof. M. A. Hapipah of the Department of Chemistry, University of Malaya, for allowing the use of her laboratory for the research and providing the analyses.

\section{References}

[1] Kundu, S., Pramanik, A. K., Mondal, A. S., Mondal, T. K., Ni(II) and Pd(II) complexes with new N,O donor thiophene appended Schiff base ligand: Synthesis, electrochemistry, X-ray structure and DFT calculation, Journal of Molecular Structure 1116 (2016) 1-8. https://doi.org/10.1016/j.molstruc.2016.03.013.

[2] Schilf, W., Kamienski, B., Szady-Chełmieniecka, A., Kołodziej, B., Grech, E., Zarzeczanska, D., Wcisło, A., Ossowski, T., Structure investigation of intramolecular hydrogen bond in some substituted salicylaldehydes and 4-aminoantipyrine derivatives in solution and in the solid state, Spectrochimica Acta Part A: Molecular and Biomolecular Spectroscopy 109 (2013) 47-54. https://doi.org/10.1016/j.saa.2013.01.094.

[3] Grivani, G., Tahmasebi, V., Eskandari, K., Khalaji, A. D., Bruno, G., Rudbari, H. A., Synthesis, characterization, crystal structure determination and computational study of the two new bidentate $\mathrm{O}, \mathrm{N}$ Schiff bases derived from bromosalicylaldehyde and amines containing alkyl halide pendant groups, Jounal of Molecular Structure 1054-1055 (2013) 100-106. https://doi.org/10.1016/j.molstruc.2013.09.026.

[4] Zayed, E. M., Zayed, M. A., Synthesis of novel Schiff's bases of highly potential biological activities and their structure investigation, Spectrochimica Acta Part A: Molecular and Biomolecular Spectroscopy 143 (2015) 81-90.

https://doi.org/10.1016/j.saa.2015.02.024.

[5] Moosavi-Tekyeh, Z., Dastani, N., Intramolecular hydrogen bonding in N-salicylideneaniline: FT-IR spectrum and quantum chemical calculations, Journal of

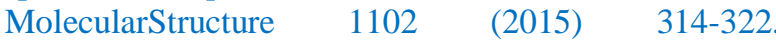
https://doi.org/10.1016/j.molstruc.2015.09.001.

[6] More, G., Raut, D., Aruna, K., Bootwala, S., Synthesis, spectroscopic characterization and antimicrobial activity evaluation of new tridentate Schiff bases and their Co(II) complexes, Journal of Saudi Chemical Society 21 (8) (2017) 954-964. https://doi.org/10.1016/j.jscs.2017.05.002.

[7] Schilf, W., Kamieński, B., Užarević, K., Nitrogen and carbon CPMAS NMR investigations of keto-enol tautomerism in asymmetric o-hydroxy Schiff bases, Journal of Molecular Structure 1031 (2013) 211-215. https://doi.org/10.1016/j.molstruc.2012.10.004.

[8] Aziz, A. A. A., Salaem, A. N. M., Sayed, M. A., Abo-Aly, M. M., Synthesis, structural characterization, thermal studies, catalytic efficiency and antimicrobial activity of some M(II) complexes with ONO tridentate Schiff base N-salicylidene-o-aminophenol ( $\mathrm{saphH}_{2}$ ), Journal of Molecular Structure 1010 (2015) 130-138. https://doi.org/10.1016/j.molstruc.2011.11.043. 
[9] Kianfar, A. H., Farrokhpour, H., Dehghani, P., Khavasi, H. R., Experimental and theorectical spectroscopic study and structural determination of nickel(II) tridentate Schiff base complexes, Spectrochimica Acta Part A: Molecular and Biomolecular Spectroscopy $150 \quad$ (2015) 220-229. https://doi.org/10.1016/j.saa.2015.05.084.

[10] Köse, M., Purtas, S., Güngör, S. A., Ceyhan, G., Akgün, E., McKee, V., A novel Schiff base: Synthesis, structural characterisation and comparative sensor studies for metal ion detections, Spectrochimica Acta. Part A, Molecular and Biomolecular Spectroscopy 136 (C) (2014) 1388-1394. https://doi.org/10.1016/j.saa.2014.10.025.

[11] Saha, S., Jana, S., Gupta, S., Ghosh, A., Nayek, H. P., Syntheses, structures and biological activities of square planar $\mathrm{Ni}(\mathrm{II}), \mathrm{Cu}(\mathrm{II})$ complexes, Polyhedron 107 (2016)

183-189. https://doi.org/10.1016/j.poly.2016.01.034.

[12] Ghosh, A. K., Mitra, M., Fathima, A., Yadav, H., Choudhury, A. R., Nair, B. U., Ghosh, R., Antibacterial and catecholase activities of $\mathrm{Co}(\mathrm{III})$ and $\mathrm{Ni}(\mathrm{II})$ Schiff base complexes, Polyhedron 107 (2016) 1-8. https://doi.org/10.1016/j.poly.2016.01.015.

[13] Chandra, S., Vandana, V. P., Synthesis, spectroscopic, anticancer, and antibacterial studies of $\mathrm{Ni}$ (II) and $\mathrm{Cu}$ (II) complex with 2carboxybenzalaldehyde thiosemicarbazone, Spectrochimica Acta Part A: Molecular Biomolecular Spectroscopy $\quad 129 \quad$ (2014) 333-338. https://doi.org/10.1016/j.saa.2014.02.141.

[14] Refat, M. S., El-Sayed, M. Y., Adam, A. M. A., Structural, Electronic and Thermal Studies of ChargeTransfer Complexes from the Schiff Base; $N, N^{\prime}$ Disalicylidene-1,2-Phenylenediamine with Chloranilic Acid, $p$-Chloranil, TCNQ and DDQ, Canadian

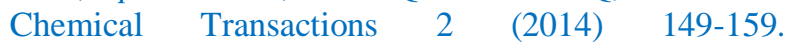
https://doi.org/10.13179/canchemtrans.2014.02.02.008 6.

[15] Maihub, A. A., Alassbaly, F. S., El-Ajaily, M. M., Etorki, A. M., Modification on Synthesis of Mixed Ligand Chelates by Using Di- and Trivalent Transition Metal Ions with Schiff Base as Primary Ligand, Green and Sustainable Chemistry 4 (3) (2014) 103-110. https://doi.org/10.4236/gsc.2014.43015.

[16] Yousif, E., Majeed, A., Al-Sammarrae, K., Salih, N., Salimon, J., Abdullah, B., Metal complexes of Schiff base: Preparation, characterization and antibacterial activity, Arabian Journal of Chemistry 10 (Supp. 2) (2017) S1639-S1644. https://doi.org/10.1016/j.arabjc.2013.06.006.
[17] Kiran, T., Prasanth, V. G., Balamurali, M. M., Vasavi, C. S., Munusami, P., Sathiyanarayanan, K. I., Pathak, M., Synthesis, spectroscopic characterization and in vitro studies of new heteroleptic copper (II) complexes derived from 2-hydroxy napthaldehyde Schiff's bases and N, N donor ligands: Antimicrobial, DNA binding and cytotoxic investigations, Inorganica

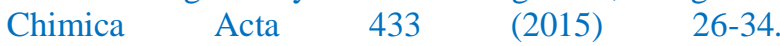
https://doi.org/10.1016/j.ica.2015.04.033.

[18] Mazlan, N. A., Ravoof, T. B. S. A., Tiekink, E. R. T., Tahir, M. I. M., Veerakumarasivam, A., Crouse, K. A., Mixed-ligand metal complexes containing an ONS Schiff base and imidazole/benzimidazole ligands: synthesis, characterization, crystallography and biological activity, Transition Metal Chemistry 39 (6) (2014) 633-639. https://doi.org/10.1007/s11243-0149842-9.

[19] Naik, K. H. K., Selvaraj, S., Naik, N., Metal complexes of ONO donor Schiff base ligand as a new class of bioactive compounds: Synthesis, characterization and biological evolution, Spectrochimica Acta Part A: Molecular and Biomolecular Spectroscopy 131 (2014) 599-605. https://doi.org/10.1016/.j.saa.2014.03.038.

[20] Ali, H. A., Fares, H., Darawsheh, M., Rappocciolo, E., Akkawi, M., Jaber, S., Synthesis, characterization and biological activity of new mixed ligand complexes of $\mathrm{Zn}(\mathrm{II})$ naproxen with nitrogen based ligands, European Journal of Medicinal Chemistry 89 (2015) $67-$ 76. https://doi.org/10.1016/j.ejmech.2014.10.032.

[21] Ololade, Z. S., Olawore, N. O., Olasoji, S. O., Anosike, S. O., Chemical Composition and Bactericidal Activities of the Leaf Essential Oil of Eucalyptus maculata Hook, Natural Products Chemistry \& Research 5 (2) (2017) 257. https://doi.org/10.4172/23296836.1000257 .

[22] Pierre, B. K., Pierre, S. H., Tatjana, S., Study of Polyphenol Content and Antioxidant Capacity of Myrianthus Arboreus (Cecropiaceae) Root Bark Extracts, Antioxidants 4 (2) (2015) 410-426. https://doi.org/10.3390/antiox4020410.

[23] Ikram, M., Rehman, S., Khan, A., Baker, R. J., Hofer, T. S., Subhan, F., Qayum, F., Faridoon, M., Schulze, C., Sythesis, characterization, antioxidant and selective xanthine oxidase inhibitory studies of transition metal complexes of novel amino acid bearing Schiff base ligand, Inorganica Chimica Acta 428 (2015) 117-126. https://doi.org/10.1016/j.ica.2015.01.021.

[24] Adekunle, F. A. O., Semire, B., Odunola, O. A., Synthesis, Characterization and Quantum Chemical Studies of $\mathrm{Ru}$ (phen) ${ }_{2} \mathrm{Cl}_{2} .2 \mathrm{H}_{2} \mathrm{O}$ and $\mathrm{Ru}$ (bipy) ${ }_{2} \mathrm{Cl}_{2} \cdot 2 \mathrm{H}_{2} \mathrm{O}$ 
with 2,6- Diacetylpyridinedihydrazone, Synthesis and Reactivity in Inorganic, Metal-Organic, and Nano-Metal $\begin{array}{lllll}\text { Chemistry } & 45 & \text { (8) (2015) 210-224. }\end{array}$ https://doi.org/10.1080/15533174.2013.862662.

[25] Annaraj, B., Pan, S., Neelakantan, M. A., Chattaraj, P. K., DFT study on the ground state and excited state intramolecular proton transfer of propargyl arm containing Schiff bases in solution and gas Phases, Computational and Theoretical Chemistry 1028 (2014) 19-26. https://doi.org/10.1016/j.comptc.2013.11.018.

[26] Paul, M. K., Singh, Y. D., Singh, N. B., Sarkar, U., Emissive bis-salicylaldiminato Schiff base ligands and their zinc(II) complexes: Synthesis, photophysical properties, mesomorphism and DFT studies, Jounal of Molecular Structure $1081 \quad$ (2015) 316-328. https://doi.org/10.1016/j.molstruc.2014.10.031.

[27] Shabbir, M., Akhter, Z., Ahmad, I., Ahmed, S., Shafiq, M., Mirza, B., Mckee, V., Munawar, K. S., Ashraf, A. R., Schiff base triphenylphoshine palladium(II) complexes: Synthesis, structural elucidation, electrochemical and biological evaluation, Journal of Molecular Structure 1118 (2016) 250-258. https://doi.org/10.1016/j.moistruc.2016.04.003.

[28] Belal, A. A. M., El-Deen, I. M., Farid, N. Y., Rosan, Z., Refat, M. S., Synthesis, spectroscopic, coordination and biological activities of some transition metal complexes containing ONO tridentate Schiff base ligand, Spectrochimica Acta Part A: Molecular and Biomolecular Spectroscopy 149 (2015) 771-789. https://doi.org/10.1016/j.saa.2015.05.005.

[29] Salehi, M., Rahimifar, F., Kubicki, M., Asadi, A., Structural, spectrocsopic, electrochemical and antibacterial studies of some new nickel(II) Schiff base complexes, Inorganica Chimica Acta 443 (2016) 28-35. https://doi.org/10.1016/j.ica.2015.12.016.

[30] Barauah, J., Borah, G., Kardong, D., Ni(II), Cu(II) and $\mathrm{Pd}(\mathrm{II})$ Complexes of Anisaldehyde-4-phenylthiosemicarbazone: synthesis, spectral characterization and biological study, Asian Journal of Chemistry 28 (11) (2016) 2446-2452. https://doi.org/10.14233/ajchem.2016.20013.

[31] Abo-Aly, M. M., Salem, A. M., Sayed, M. A., Aziz, A. A. A., Spectroscopic and structural studies of the Schiff base 3-methoxy-N-salicylidene-o-amino phenol complexes with some transition metal ions and their antibacterial, antifungal activities, Spectrochimica Acta Part A: Molecular and Biomolecular Spectroscopy 136 (B) (2015) 993-1000. https://doi.org/10.1016/j.saa.2014.09.122. 